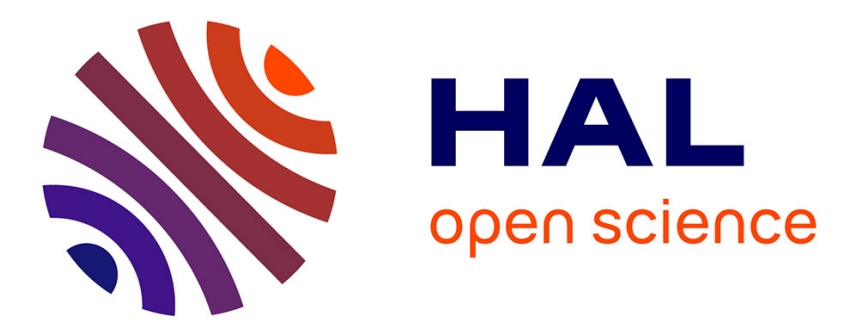

\title{
5-hydroxymethylcytosine marks postmitotic neural cells in the adult and developing vertebrate central nervous system
}

\author{
Nicolas Diotel, Yohann Mérot, Pascal Coumailleau, Marie-Madeleine \\ Gueguen, Aurélien Sérandour, Gilles Salbert, Olivier Kah
}

\section{To cite this version:}

Nicolas Diotel, Yohann Mérot, Pascal Coumailleau, Marie-Madeleine Gueguen, Aurélien Sérandour, et al.. 5-hydroxymethylcytosine marks postmitotic neural cells in the adult and developing vertebrate central nervous system. Journal of Comparative Neurology, 2017, 525 (3), pp.478-497. 10.1002/cne.24077 . hal-01439354

HAL Id: hal-01439354

https://hal-univ-rennes1.archives-ouvertes.fr/hal-01439354

Submitted on 6 Feb 2018

HAL is a multi-disciplinary open access archive for the deposit and dissemination of scientific research documents, whether they are published or not. The documents may come from teaching and research institutions in France or abroad, or from public or private research centers.
L'archive ouverte pluridisciplinaire HAL, est destinée au dépôt et à la diffusion de documents scientifiques de niveau recherche, publiés ou non, émanant des établissements d'enseignement et de recherche français ou étrangers, des laboratoires publics ou privés. 


\title{
5-Hydroxymethylcytosine Marks Postmitotic Neural Cells in the Adult and Developing Vertebrate Central Nervous System
}

\author{
Nicolas Diotel, ${ }^{1,2,3 \ddagger \star *}$ Yohann Mérot, ${ }^{3 \dagger}$ Pascal Coumailleau, ${ }^{3}$ Marie-Madeleine Gueguen, ${ }^{3}$ \\ Aurélien A. Sérandour, ${ }^{4 \ddagger}$ Gilles Salbert, ${ }^{4 \star}$ and Olivier $\mathrm{Kah}^{3}$ \\ ${ }^{1}$ Inserm, UMR 1188 Diabète athérothrombose Thérapies Réunion Océan Indien (DéTROI), plateforme CYROI, \\ Université de La Réunion, UMR 1188, Sainte-Clotilde, France \\ ${ }^{2}$ Université de La Réunion, UMR 1188, Sainte-Clotilde, France \\ ${ }^{3}$ Inserm, UMR 1085, Research Institute in Health, Environment and Occupation, Institut National de la Santé et de la Recherche \\ Médicale U1085, Université de Rennes 1, SFR Biosite, 9 avenue du Prof. Léon Bernard - Rennes, France \\ ${ }^{4}$ UMR 6290 CNRS, IGDR, Université de Rennes 1, Campus de Beaulieu, Rennes, France \\ ${ }^{5}$ Current address for Aurélien A. Sérandour: EMBL, Meyerhofstrasse 1, Heidelberg 69117, Germany
}

\begin{abstract}
The epigenetic mark 5-hydroxymethylcytosine $(5 \mathrm{hmC})$ is a cytosine modification that is abundant in the central nervous system of mammals and which results from 5methylcytosine oxidation by TET enzymes. Such a mark is suggested to play key roles in the regulation of chromatin structure and gene expression. However, its precise functions still remain poorly understood and information about its distribution in non-mammalian species is still lacking. Here, the distribution of $5 \mathrm{hmC}$ was investigated in the brain of adult zebrafish, African claw frog, and mouse in a comparative manner. We show that zebrafish neurons are endowed with high levels of $5 \mathrm{hmC}$, whereas quiescent or proliferative neural progenitors show low to undetectable levels of the
\end{abstract}

modified cytosine. In the brain of larval and juvenile Xenopus, $5 \mathrm{hmC}$ is also detected in neurons, while ventricular proliferative cells do not display this epigenetic mark. Similarly, $5 \mathrm{hmC}$ is enriched in neurons compared to neural progenitors of the ventricular zone in the mouse developing cortex. Interestingly, $5 \mathrm{hmC}$ colocalized with the methylated DNA binding protein MeCP2 and with the active chromatin histone modification H3K4me2 in mouse neurons. Taken together, our results show an evolutionarily conserved cerebral distribution of $5 \mathrm{hmC}$ between fish and tetrapods and reinforce the idea that $5 \mathrm{hmC}$ fulfills major functions in the control of chromatin activity in vertebrate neurons. J. Comp. Neurol. 000:000-000, 2016.
In multicellular organisms, cells display an identical genome but exhibit distinct cellular phenotypes due to the establishment of unique gene expression profiles during developmental cell fate specification. Such specific expression profiles are believed to rely on epigenetic modifications leading to the establishment of cellspecific chromatin states. In vertebrates, DNA methylation is an important epigenetic modification that controls tissue development and differentiation (Baranzini et al., 2010; Meng et al., 2015). In vertebrates, DNA methylation consists of the addition of a methyl group to the fifth carbon of cytosine $(5 \mathrm{mC})$, mainly in a CpG dinucleotide context. Such DNA modification allows the regulation of a wide range of cellular processes such as embryonic development, transcription, X-chromosome inactivation, and also genomic imprinting (Meng et al.,

\footnotetext{
${ }^{\dagger}$ The first two authors contributed equally to this work.

${ }^{*}$ CORRESPONDENCE TO: N. Diotel or G. Salbert, Inserm, UMR 1188 Diabète athérothrombose Thérapies Réunion Océan Indien (DéTROI), plateforme CYROI, Université de La Réunion, UMR 1188, Sainte-Clotilde, F97490, France. E-mail: nicolas.diotel@univ-reunion.fr or gilles.salbert@ univ-rennes $1 . \mathrm{fr}$

${ }^{\mp}$ Current address for Aurélien A. Sérandour: EMBL, Meyerhofstrasse 1, Heidelberg 69117, Germany
} 
2015). In mammals, DNA methylation is catalyzed by three enzymatically active DNA methyltransferases (Dnmts): Dnmt1, Dnmt3a, and Dnmt3b (Reik, 2007). Dnmt3a and $3 \mathrm{~b}$ are de novo methyltransferases that act on unmethylated DNA to establish new DNA methylation patterns. Dnmt1 preferentially methylates hemi-methylated $\mathrm{CpGs}$ (such as those generated by DNA replication) and is considered a maintenance methyltransferase preserving DNA methylation patterns through cell division. As shown by Dnmt disruption, the establishment and maintenance of $\mathrm{CpG}$ methylation patterns are crucial for proper development and viability of embryos ( $\mathrm{Li}$ et al., 1992; Okano et al., 1999). Although $5 \mathrm{mC}$ is a major epigenetic mark regulating crucial aspects of genome functions (Suzuki and Bird, 2008 ), the traditional view of $5 \mathrm{mC}$ as being a stable covalent modification of DNA in the vertebrate genome has recently been challenged by the discovery that it can be oxidized to generate 5-hydroxymethylcytosine $(5 \mathrm{hmC})$, a modified DNA residue that is physiologically relevant in neuronal cells and in embryonic stem cells (ES cells) (Kriaucionis and Heintz, 2009; Tahiliani et al., 2009). Since then, other modified cytosines have been described in mammals, including 5-formylcytosine (5fC) and 5-carboxylcytosine $(5 \mathrm{caC})$ (Kriaucionis and Heintz, 2009; Tahiliani et al., 2009; Maiti and Drohat, 2011; Meng et al., 2015). Oxidation of $5 \mathrm{mC}$ to $5 \mathrm{hmC}, 5 \mathrm{fC}$, and $5 \mathrm{caC}$ is catalyzed by the ten-eleven translocation (Tet) family of enzymes, which comprises three members (Tet1, Tet2, and Tet3). Although the $5 \mathrm{hmC}$ epigenetic mark appears to be relatively stable and abundant in mammalian genomes, $5 \mathrm{fC}$ and $5 \mathrm{caC}$ are more labile entities that are recognized and processed by the DNA glycosylase TDG and the base excision repair machinery (Globisch et al., 2010; Wu and Zhang, 2010; Cheng et al., 2015a,b). Interestingly, the highest levels of $5 \mathrm{hmC}$ are detected in the central nervous system (CNS), in neurons (Globisch et al., 2010; Munzel et al., 2010; Szwagierczak et al., 2010). Recent publications described the expression of $5 \mathrm{hmC}$ in the brain of rat (Zheng et al., 2015), of mouse and human (Jin et al., 2011; Chen et al., 2012; Kraus et al., 2015), and also of zebrafish brain during development (Almeida et al., 2012). In addition, high levels of $5 \mathrm{hmC}$ have been found in the spinal cord of the amphibian axolotl (Almeida et al., 2012b). In mammals, $5 \mathrm{hmC}$ has been shown to be enriched, notably in the cerebral cortex, the hippocampus, and the cerebellum (Chen et al., 2012; Kraus et al., 2015; Zheng et al., 2015). Interestingly, $5 \mathrm{hmC}$ content was shown to increase during aging with no concomitant $5 \mathrm{mC}$ decrease, suggesting that $5 \mathrm{hmC}$ could act as a real epigenetic mark (Chen et al., 2012). However, the precise function of $5 \mathrm{hmC}$ is currently unclear. A recent study focusing on the dynamics of $5 \mathrm{hmC}$ and chromatin marks during mammalian neurogenesis show that $5 \mathrm{hmC}$ levels increase during neuronal differentiation and that $5 \mathrm{hmC}$ enrichment is not associated with DNA demethylation in neurons, suggesting that $5 \mathrm{hmC}$ is a stable epigenetic mark (Hahn et al., 2013). Given the specific distribution of $5 \mathrm{hmC}$ in the brain of mammals, and its role in gene expression, $5 \mathrm{hmC}$ was envisioned as a key player in brain development and is suggested to play roles in neurological disorders (Cheng et al., 2015a,b). Given its implication in ES cell self-renewal and differentiation, $5 \mathrm{hmC}$ could also regulate neurogenic processes such as neural stem cell proliferation, neuronal fate, and differentiation (Ito et al., 2010; Ficz et al., 2011; Pastor et al., 2011). Interestingly, adult neurogenesis is an evolutionarily conserved feature of the CNS across the animal kingdom. In mammals, adult neurogenesis is mainly restricted to two regions of the telencephalon: the subventricular zone (SVZ) of the lateral ventricle and the subgranular zone (SGZ) of the dentate gyrus in the hippocampus (Lindsey and Tropepe, 2006; Grandel and Brand, 2013; Braun and Jessberger, 2014). In striking contrast, non-mammalian vertebrates such as fish and amphibians exhibit a more intense neurogenic activity (Lindsey and Tropepe, 2006; Kah et al., 2009; D'Amico et al., 2011). Adult zebrafish exhibit a widespread neurogenic activity throughout the brain (Kah et al., 2009; Diotel et al., 2010a; Kizil et al., 2012; Edelmann et al., 2013; Schmidt et al., 2013; Pellegrini et al., 2015) and possess a high regenerative capacity for repairing lesions of the CNS (Zupanc et al., 2005; Lindsey and Tropepe, 2006; Zupanc, 2008; März et al., 2011; Diotel et al., 2013; Grandel and Brand, 2013; Pellegrini et al., 2015). In zebrafish, such a strong neurogenic activity is due to the persistence of neural progenitors in adulthood, radial glia cells and further committed progenitors corresponding to neuroblasts (Adolf et al., 2006; Pellegrini et al., 2007; März et al., 2010; Lindsey et al., 2012; Schmidt et al., 2013). Hence, the brain of adult zebrafish retains features of the embryonic mammalian brain (Diotel et al., 2010a). In addition, brain proliferation has been recently shown in the developing brain of anuran through larval and metamorphic development, notably in Xenopus, the highest levels of proliferative cells being detected in the telencephalic ventricular layers (Raucci et al., 2006; Coen et al., 2007; Denver et al., 2009; D’Amico et al., 2011, 2013).

In this work we describe the distribution of $5 \mathrm{hmC}$ and its relationship with differentiating neurons and dividing neural progenitors in zebrafish, Xenopus, and mouse brain. In favor of a role in terminal differentiation 
of vertebrate neurons, our data show that in all three species examined $5 \mathrm{hmC}$ is selectively enriched in differentiating nondividing cells.

\section{MATERIAL AND METHODS \\ Ethics}

This study was approved by the ethics committee CREEA (Comité Rennais d'Ethique en matière d'Expérimentation Animale), permit number EEA B-35-040. The zebrafish, Xenopus, and mice were kept, handled, and sacrificed in accordance with European Union regulations concerning the protection of experimental animals. Experiments were performed by authorized investigators (Permit number: 75-390).

\section{Animals and brain dissection}

Experiments were performed on male wildtype adult zebrafish (Danio rerio) or on the transgenic zebrafish line $\operatorname{tg}($ cyp19a1b-GFP) expressing green fluorescent protein (GFP) in radial glial cells under the control of the cyp19a1b promoter (Tong et al., 2009). Fish were housed in the zebrafish facility of the SFR Biosit (INRA SCRIBE, Rennes, France) and maintained under standard conditions of temperature $\left(28.5^{\circ} \mathrm{C}\right)$ and photoperiod (14/10 hours light/dark). Xenopus laevis were bred and maintained under standard husbandry conditions in France at the Xenopus Center of Biological Resource (CRB; University of Rennes 1; htp://xenopus.univ -rennes 1.fr). For sacrifice, fish were anesthetized with tricaine (MS-222) before sectioning the spinal cord. Brains were partially dissected through skull opening and fish were immersed overnight at $4{ }^{\circ} \mathrm{C}$ in $4 \%$ paraformaldehyde (PFA) in saline phosphate buffer (PBS, $\mathrm{pH}$ 7.4). On the next day, brains were taken out and fixed at $4{ }^{\circ} \mathrm{C}$ in $4 \%$ PFA, in order to be entirely processed for paraffin inclusion. Larvae and juvenile Xenopus were obtained, staged, and sacrificed as previously described (Coumailleau and Kah, 2014).

Swiss mice were housed on a 12-hour light/dark cycle. For embryos staging, detection of a vaginal plug at noon was designated as embryonic day 0.5 (E0.5) and the day of birth as PO. Embryonic and neonate brains were dissected and fixed overnight in 4\% PFA. For adult brains, 3-month-old mice were euthanized by cervical dislocation and the removed brain were fixed for 48 hours in $4 \%$ PFA.

For this study, the number of animals used was as follows: 3-6-month-old zebrafish were used ( $n=5$ wildtype; $n=5$ transgenic), larvae (Stage 50, $n=4$ ) and juvenile (Stage 66, $n=4$ ) Xenopus, 3-month-old adult male mice $(n=3)$ and E14.5 to P7 mice $(n=48)$.

\section{Immunohistochemistry}

For the immunohistochemistry protocol, paraffin sections $(7 \mu \mathrm{m})$ of wildtype or cyp19a1b-GFP transgenic zebrafish brains were prepared using a microtome (Microm HM 355 S), and cryosections were made for Xenopus. Paraffin sections were next deparaffinized in OTTIX, rehydrated through graded ethanol (100-30\%), and rinsed in PBS (pH 7.4). Zebrafish and Xenopus brain sections were then placed in $2 \mathrm{~N} \mathrm{HCl}$ buffer at $37^{\circ} \mathrm{C}$ for 30 minutes, followed by two washes of 5 minutes in $0.1 \mathrm{M}$ sodium tetraborate decahydrate $(\mathrm{pH} 8.5)$ at room temperature. Slides were rinsed in $0.2 \%$ Triton PBS and incubated in PBS containing $0.5 \%$ of milk powder overnight with appropriate primary antibodies: anti5hmC (1:100-1:500, Diagenode, Seraing, Belgium; C15410205; RRID: AB_2572206), anti-proliferating cell nuclear antigen (PCNA) (1:100; Clone PC10; Dako, Glostrup, Denmark; REF: M0879; RRID: AB_2160651), and antiacetylated tubulin (1:50; Sigma-Aldrich, St. Louis, MO; REF: T6793, RRID:AB_477585). On the next day, sections were washed three times in $0.2 \%$ Triton PBS and incubated with the secondary antibody (Alexa Fluor goat antimouse and/or goat antirabbit 488 and/ or 594; 1:200; Invitrogen Molecular Probes, Eugene, OR; RRID: AB_141607, RRID: AB_10049650, RRID: $\left.A B \_141372\right)$. Tissue sections were washed several times in PBS containing $0.2 \%$ Triton and slides were mounted with the antifading medium Vectashield (Vector Laboratories, Burlingame, CA) with or without 4,6diamino-2-phenylindole (DAPI) that permits visualization of cell nuclei.

Mice brain sections $(30-50 \mu \mathrm{m})$ were cut coronally using a vibratome (VT1000s; Leica). For immunolabeling of $5 \mathrm{hmC}$ and $5 \mathrm{mC}$, free-floating sections were incubated 30 minutes in citrate buffer $(\mathrm{pH} 6)$ at $80^{\circ} \mathrm{C}$ followed by incubation in $2 \mathrm{~N} \mathrm{HCl}$ for 30 minutes at room temperature (antigen retrieval). Sections were then washed and equilibrated in PBS/0.1\% Tween-20 (PBST) and incubated overnight at $4{ }^{\circ} \mathrm{C}$ in primary antibody diluted in PBST. Primary antibodies included rabbit polyclonal 5hmC (1:3,000; Diagenode, C15410205; RRID: $\left.A B \_2572206\right)$, mouse polyclonal $5 \mathrm{mC}$ (1:100; Diagenode, C15200081; RRID: AB_2572207), MeCP2 (1:200; Active Motif, 61285; RRID: AB_2572268), H3K4me2 (1/1,000; Millipore, Bedford, MA; 05-1338; RRID: AB_1977248), PCNA (1:400; Clone PC10; Dako; REF: M0879; RRID: AB_2160651). The following day, sections were washed in PBST, exposed for 1 hour 30 minutes to the appropriate secondary antibodies (1:500; Invitrogen Molecular Probes; RRID: AB_141607, RRID: AB_10049650, RRID: AB_141372), and washed again. For double labeling experiments with $5 \mathrm{hmC}$ or 
TABLE 1.

Primary and Secondary Antibodies

\begin{tabular}{|c|c|c|c|}
\hline \multicolumn{4}{|l|}{ Primary antibodies } \\
\hline Antibodies & Reference & RRID & Antigen \\
\hline 5-hmC polyclonal antibody & C15410205-50 (Diagenode) & AB_2572206 & 5-hydroxymethylcytosine \\
\hline 5-mC monoclonal antibody 33D3 & C15200081-100 (Diagenode) & AB_2572207 & 5-methylcytosine \\
\hline MeCP2 antibody & 61285 (Active Motif) & AB_2572268 & full-length protein of rat MeCP2 \\
\hline $\begin{array}{l}\text { Anti-dimethyl histone H3 (Lys4) } \\
\text { antibody (H3K4me2 antibody) }\end{array}$ & 05-1338 (Millipore) & AB_1977248 & $\begin{array}{l}\text { Synthetic peptide corresponding } \\
\text { to amino acids } 1-12 \text { of human } \\
\text { Histone } \mathrm{H} 3 \text {, dimethylated on } \\
\text { Lys } 4 \text {, conjugated to KLH. }\end{array}$ \\
\hline $\begin{array}{l}\text { Proliferating cell nuclear antigen } \\
\text { clone PC } 10\end{array}$ & M0879 (DAKO) & AB_2160651 & $\begin{array}{l}\text { Rat PCNA-protein A fusion protein } \\
\text { obtained from vector pC2T } \\
\text { (Waseem and Lane, 1990) }\end{array}$ \\
\hline $\begin{array}{l}\text { Mouse anti-tubulin, acetylated } \\
\text { monoclonal antibody }\end{array}$ & Clone 6-11B-1 T6793 (Sigma-Aldrich) & AB_477585 & $\begin{array}{l}\text { Acetylated } \alpha \text {-tubulin from the } \\
\text { outer arm of sea urchin sperm } \\
\text { axonemes. }\end{array}$ \\
\hline \multicolumn{4}{|l|}{ Secondary antibodies } \\
\hline Antibodies & \multicolumn{2}{|l|}{ Reference } & RRID \\
\hline Donkey antimouse Alexa fluor 488 & \multicolumn{2}{|c|}{ A21202 (Molecular Probes, Life Technologies) } & $A B \_141607$ \\
\hline Donkey antirabbit Alexa fluor 488 & \multirow{2}{*}{\multicolumn{2}{|c|}{$\begin{array}{l}\text { A21206 (Molecular Probes, Life Technologies) } \\
\text { A11005 (Molecular Probes, Life Technologies) }\end{array}$}} & $A B \_10049650$ \\
\hline Goat antimouse Alexa fluor 594 & & & $A B_{-} \_141372$ \\
\hline
\end{tabular}

$5 \mathrm{mC}$, immunostaining procedures were performed sequentially, i.e., the antigen retrieval for $5 \mathrm{hmC}$ or $5 \mathrm{mC}$ staining were performed after a postfixation step (15 minutes in 4\% PFA) following the first immunodetection. After immunohistological staining, sections were counterstained with DAPI and mounted on slides. Stained sections were visualized using an apotome microscope (Axiolmager Z1, Zeiss) and a confocal microscope (Leica SP8).

In all immunohistochemistry experiments, no staining was observed after omission of the primary antibodies or with incubation with corresponding rabbit immunoglobulin fraction and negative control mouse IgG (data not shown). The antibodies used in this study are provided in Table 1.

\section{Riboprobe synthesis and in situ hybridization}

cDNA of mouse Tet1 (nt 4824-5957 in the coding sequence), Tet2 (nt 523-1724), Tet3 (nt 1228-2403) were inserted in the pCRII TOPO dual promoter vector according to the manufacturer's instructions (Invitrogen, Gercy Pontoise, France). Antisense and sense singlestranded mRNA probes were obtained with DIG RNA labeling MIX (Roche, Indianapolis, IN) by transcription with T7 and SP6 polymerase (Promega, Madison, WI) on pCRII plasmids linearized with appropriate restriction enzymes.

Before the hybridization procedure, serial transverse paraffin sections (12 $\mu \mathrm{m}$ thick) were deparaffinized and rehydrated as described above for zebrafish paraffin sections. After a postfixation step in 4\% PFA diluted in PBS for 20 minutes, sections were washed in PBS and then incubated in proteinase $\mathrm{K}$ for 3 minutes at room temperature $(10 \mathrm{mg} / \mathrm{ml}$ in $50 \mathrm{mM}$ Tris- $\mathrm{HCl}, \mathrm{pH} 8.0$, $5 \mathrm{mM}$ EDTA). After a novel postfixation step, sections were rinsed twice in saline-sodium citrate (SSC) $2 \times$ at room temperature. Hybridization was performed overnight at $65^{\circ} \mathrm{C}$ in a humidified chamber using $100 \mu \mathrm{l}$ of hybridization buffer ( $2 \times$ SSC; $2.5 \%$ dextran sulfate; $50 \%$ deionized formamide; $5 \times$ Denhardt's solution; $50 \mu \mathrm{g} /$ $\mathrm{ml}$ of yeast tRNA, $\mathrm{pH} 8.0 ; 4 \mathrm{mM}$ EDTA) containing the DIG-labeled probes $(5 \mu \mathrm{g} / \mathrm{ml})$. On the next day, slides were rinsed in $2 \times \mathrm{SSC}$ at $65^{\circ} \mathrm{C}$, followed by two rinses at $65^{\circ} \mathrm{C}(2 \times 30$ minutes $)$ in $2 \times \mathrm{SSC} / 50 \%$ formamide. Final rinses were made in 0.2 and $0.1 \times$ SSC at room temperature. Following an incubation in PBST for 10 minutes, sections were incubated in PBST containing $0.5 \%$ blocking reagent for 30 minutes. They were then incubated overnight at room temperature with anti-DIG Biotin conjugate (Perkin Elmer, Boston, MA; NEF833001EA 1/1,000). The next day, sections were washed with PBST and processed for fluorescent revelation with the TSA kit as recommended by the manufacturer (ThermoFisher Scientific, Pittsburgh, PA; T-20932). No staining was obtained with the respective sense probes, as shown in Figure 9.

\section{Real-time polymerase chain reaction (PCR)}

Two $\mu \mathrm{g}$ total RNA were reverse-transcribed using $5 \mathrm{mM}$ random hexamer oligonucleotides and $100 \mathrm{U}$ of 
Moloney Murine Leukemia Virus Reverse Transcriptase as recommended by the manufacturer (Promega). PCR reactions were performed in an iCycler thermocycler coupled to the MyiQ detector (Bio-Rad, Hercules, CA) using iQ SYBR-Green Supermix (Bio-Rad) according to the manufacturer's protocol. The following primers were used: Tet1 (fw) 5'-CCTTTTCGTGTGTCCCTTGT-3', Tet1 (rev) 5'-TCTCGGGTTAAGGTTGATGC-3'; Tet2 (fw) 5'GTTCTCAACGAGCAGGAAGG-3', Tet2 (rev) 5'-TGAGAT GCGGTACTCTGCA-3'; Tet3 (fw) 5'-TCCGGATTGAGAA GGTCATC-3', Tet3 (rev) 5'-CCAGGCCAGGATCAAGATAA3'; ribosomal protein S28 (Rps28) (fW) 5'-CGATCCATCA TCCGCAATG-3', $\quad$ Rps28 (rev) 5'-AGCCAAGCTCAGCG CAAC-3'. Expression levels of Rps28 mRNA were used to normalize the expression levels of the other genes. Correct amplifications were assessed by melting curve and PCR efficiency analyses. Real-time PCR was performed on three different animals for each stage studied.

\section{Antibody specificity}

As expected from antibodies recognizing modified bases in DNA, $5 \mathrm{mC}$ and $5 \mathrm{hmC}$ antibodies work in all tested vertebrate species. According to the manufacturer's datasheet, dotblot assay shows no crossreactivity of the $5 \mathrm{hmC}$ antibody with 5-methylcytosine and cytosine. Similarly, $5 \mathrm{mC}$ antibody is shown to react in mouse and dotblot assay shows no crossreactivity of this antibody with $5 \mathrm{hmC}$ and cytosine (manufacturer's datasheet). MeCP2 antibody reacts in mouse and H3K4me2 antibody in vertebrates (manufacturer's datasheet). PCNA antibody is well characterized in vertebrates including zebrafish and Xenopus (Pellegrini et al., 2007; D'Amico et al., 2011).

\section{Microscopy}

The slides were observed with an epifluorescence microscope (Olympus Provis, equipped with a DP71 digital camera), an epifluorescence Zeiss (Imager Z1, equipped with the Apotome module), or a confocal microscope (Leica SP8). Images were processed with either the Olympus Analysis, Zeiss Cell or Image (NIH, Bethesda, MD) softwares. Micrographs were generated in the "TIFF" format and adjusted for light and contrast before being assembled on plates using Photoshop CS4 (Adobe Systems, San Jose, CA). The nomenclature is according to the zebrafish atlas (Wullimann et al., 1996).

\section{RESULTS}

\section{$5 \mathrm{hmC}$-positive cells are widely distributed in the whole zebrafish brain}

In order to investigate the distribution of $5 \mathrm{hmC}$ in the CNS of adult zebrafish, we performed immunohistochemistry on transverse sections of adult brain. Cells positive for $5 \mathrm{hmC}$ were widely detected through the whole encephalon (Figs. 1-3). In the olfactory bulbs, $5 \mathrm{hmC}$-positive cells were mainly detected in the granular cell layer (data not shown). More caudally, in the telencephalon, $5 \mathrm{hmC}$ staining was detected in the pallium (Figs. 1B,F, 3M,Q) notably in the medial $(\mathrm{Dm})$, lateral, and posterior zone of the dorsal telencephalic and also in the subpallium (Figs. 1J, 2A, 3A,E,I), such as in the central, ventral $(\mathrm{Vv})$, and dorsal $(\mathrm{Vd})$ nuclei of the ventral telencephalon (Fig. 1B,J). We also detected $5 \mathrm{hmC}$ labeling in the anterior ( $\mathrm{PPa}$ ) and posterior part of the preoptic area (Fig. 2E and data not shown), the mediobasal hypothalamus as well as in regions surrounding the lateral and posterior recess (PR) of the caudal hypothalamus (Fig. $1 \mathrm{~N}$ and data not shown). Numerous 5hmC-positive cells were also observed in the optic tectum ( $\mathrm{TeO})$, notably in the periventricular gray zone (PGZ) (Fig. 2I). Overall, the wide distribution of $5 \mathrm{hmC}$-positive cells was clearly reminiscent of the distribution of neurons in the brain of adult zebrafish, suggesting that $5 \mathrm{hmC}$ could be a neuronal marker in this species.

\section{Neurons display the $5 \mathrm{hm} \mathrm{C}$ epigenetic mark in the zebrafish brain}

Given the strong expression of $5 \mathrm{hmC}$ in neuronal cells in mammals and $5 \mathrm{hmC}$ distribution in the brain of adult zebrafish, we next performed double immunohistochemistry for $5 \mathrm{hmC}$ and acetylated tubulin, a neuronal marker, in order to identify the nature of $5 \mathrm{hmC}$-positive cells in the brain of adult zebrafish. Data clearly showed that neurons strongly display the $5 \mathrm{hmC}$ epigenetic mark as shown for example in the ventral and dorsal nuclei of the ventral telencephalon (Fig. 2A$\mathrm{D}$; $\mathrm{V} v$ and $\mathrm{Vd}$ ), the anterior part of the preoptic area (Fig. 2E-H; PPa), or also in periventricular gray zone of the optic tectum (Fig. 2I-L; TeO). Such a neuronal expression is widely observed in the whole brain (data not shown) and most 5hmC-positive cells obviously correspond to neurons, similar to what was previously described in mammals.

\section{Neural progenitors do not display the $5 \mathrm{hmC}$ mark in adult zebrafish}

In the adult zebrafish telencephalon, the entire ventricular zone produces new neurons that integrate into existing neural networks (Lindsey and Tropepe, 2006; Chapouton et al., 2007; Kah et al., 2009; Diotel et al., 2010a; März et al., 2010; Grandel and Brand, 2013). Such a strong neurogenic activity is due to the persistence of neural progenitors in the brain of adult 


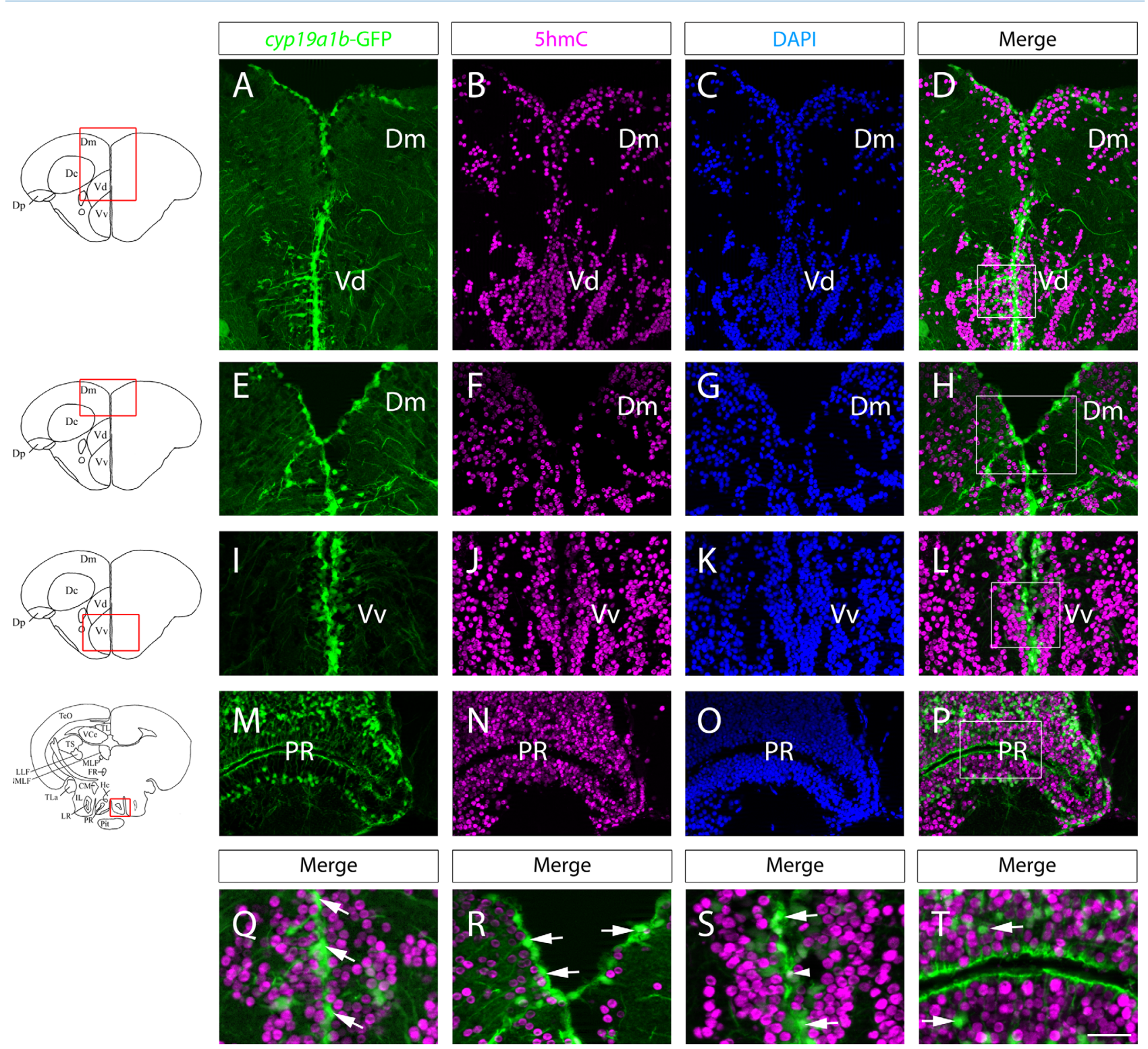

Figure 1. $5 \mathrm{hmC}$-positive cells are widely distributed in the forebrain of adult zebrafish but $5 \mathrm{hmC}$ is excluded from cyp 19a1b-GFP radial glial cells. $5 \mathrm{hmC}$ immunohistochemistry (magenta) on cyp19a1b-GFP transgenic fish (green) with cell nuclei staining (blue). A-L: the $5 \mathrm{hmC}$ epigenetic mark is widely distributed in the whole zebrafish telencephalon, notably in the dorsomedian telencephalon (Dm), the ventral $(\mathrm{Vv})$, and dorsal $(\mathrm{Vd})$ nuclei of the ventral telencephalic area. M-P: Numerous $5 \mathrm{hmC}$-positive cells are also detected in the caudal hypothalamus such as in the nucleus surrounding the posterior recess (PR). Q-T: High-power views of the respective framed boxes in D,H,L, and $\mathrm{P}$ showing that most cyp19a1b-GFP-positive radial glial cells are $5 \mathrm{hmC}$-negative (arrows). In these pictures, only one cyp19a1b-GFP positive cell is $5 \mathrm{hmC}$-positive (arrowhead). Scale bar $=35 \mu \mathrm{m}$ for $\mathrm{Q}-\mathrm{T} ; 140 \mu \mathrm{m}$ for A-P.

zebrafish. Type 1 and type 2 progenitors correspond to quiescent and actively dividing radial glial cells, respectively, while type 3 progenitors are believed to be actively dividing neuroblasts (März et al., 2010; Schmidt et al., 2013). Radial glial cells exhibit a wide variety of specific marker in the brain of adult zebrafish, such as Blbp (brain lipid binding protein), Gfap (glial fibrillary acidic protein), S100 $\beta$ (S100 calcium binding protein B), Cxcr4 (C-X-C chemokine receptor type 4), Id 1 (inhibitor of DNA binding 1, a transcription regulator), and also the estrogen-synthesizing enzyme, aromatase B (AroB), encoded by the cyp19a1b gene (Menuet et al., 2005; Tong et al., 2009; Diotel et al., 2010b, 2015; März et al., 2010; Dinarello, 2012; Coumailleau et al., 2015; Rodriguez Viales et al., 2015). In order to investigate the presence of $5 \mathrm{hmC}$ in radial glial cells, we took advantage of a cyp19a1b-GFP transgenic fish line in which GFP is expressed in radial glial cells. In 

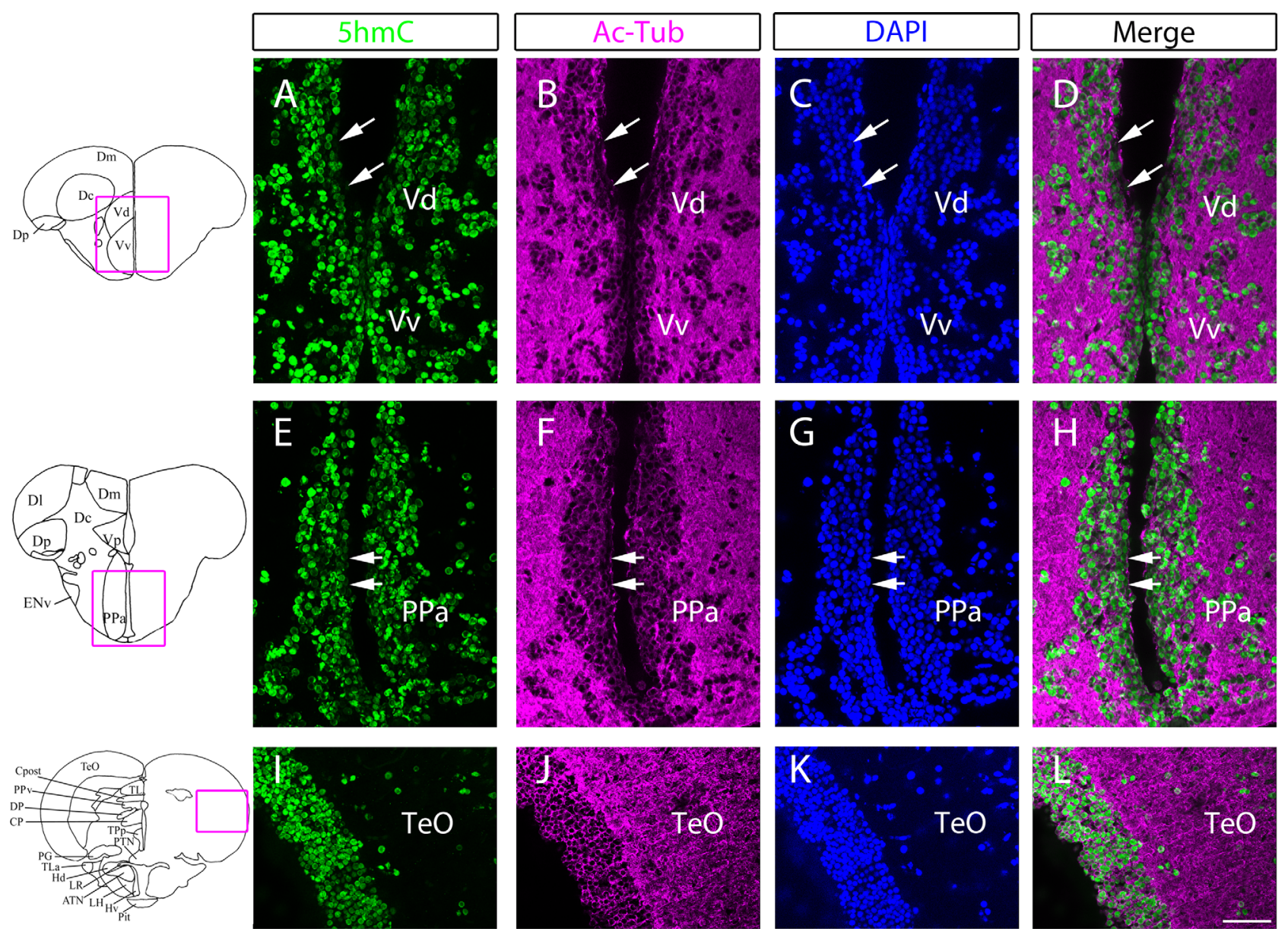

Figure 2. Most 5hmC-positive cells correspond to acetylated tubulin-positive neurons in the brain of adult zebrafish. Double immunostainings for $5 \mathrm{hmC}$ (green) and the acetylated tubulin neuronal marker (magenta) with cell nuclei staining (blue). A-L: Most 5hmC-positive cells correspond to acetylated tubulin neurons in the ventral $(\mathrm{Vv})$ and dorsal $(\mathrm{Vd})$ nuclei of the ventral telencephalic area, in the anterior part of the preoptic area (PPa), and in the periventricular gray zone (PGZ) of the optic tectum (TeO). Note that the ventricular cells that do not express the acetylated tubulin marker are $5 \mathrm{hmC}$ negative (Arrows). Scale bar $=70 \mu \mathrm{m}$.

the ventral and dorsal nucleus of the ventral telencephalic area (Fig. 1A-D,I-L; $V v$ and $V d$ ), the dorsomedian telencephalon (Fig. $1 \mathrm{~A}-\mathrm{H} ; \mathrm{Dm}$ ), and also in the nucleus of the posterior recess (Fig. 1M-P), we did not observe any convincing $5 \mathrm{hmC}$ signal in GFP-expressing cells, as obviously demonstrated by higher magnification views (Fig. 1Q-T, arrows). Only rare cyp19a1b-GFP expressing cells appeared to be very weakly $5 \mathrm{hmC}$-positive (Fig. 1S, arrowhead). Such results suggest that radial glial cells, which act as neural progenitors and generate news neurons (Pellegrini et al., 2007; Rothenaigner et al., 2011), are 5hmC-negative.

In order to reinforce the hypothesis that dividing progenitors do not widely display the $5 \mathrm{hmC}$ mark, we performed double immunohistochemistry for PCNA (a cell proliferation marker) and $5 \mathrm{hmC}$. We clearly observed that $5 \mathrm{hmC}$ labeling is not detected in most ventricular PCNA-positive cells in the telencephalon (Fig. 3).
Indeed, in the rostral migratory stream (RMS) domain composed of fast-dividing type 3 progenitors, most PCNA-positive cells were obviously $5 \mathrm{hmC}$-negative (Fig. 3A-L, arrows). Only a few rare PCNA-positive cells of the RMS displayed a significant $5 \mathrm{hmC}$ staining (Fig. 31$\mathrm{L}$, arrowheads). In the dorsomedian telencephalon, proliferative cells were also 5hmC-negative (Fig. 3M-T, arrow). Taken together, these results show that most types 1, 2, and 3 progenitors do not have detectable levels of $5 \mathrm{hmC}$, whereas the modified cytosine is enriched in newborn neurons generated by such cells.

\section{$5 \mathrm{hmc}$ mark in larval and juvenile Xenopus is expressed in neurons but not in proliferative cells}

In order to investigate the distribution of the $5 \mathrm{hmC}$ epigenetic mark in another vertebrate model and to 

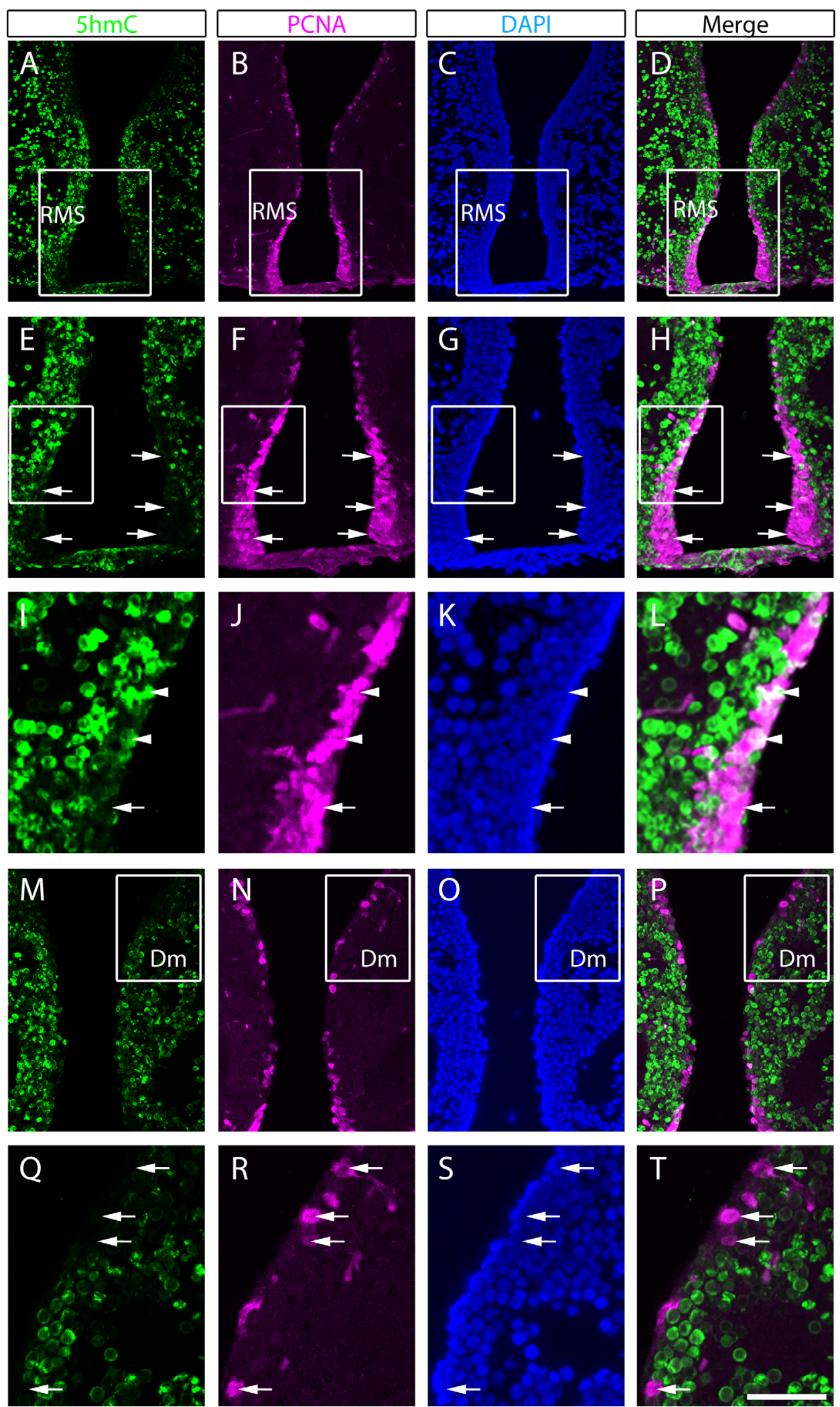

Figure 3. Proliferative cells are $5 \mathrm{hmC}$-negative in the anterior brain of adult zebrafish. Double immunostainings for $5 \mathrm{hmC}$ (green) and the proliferative marker PCNA (magenta) with cell nuclei staining (blue). A-H: Fast proliferating progenitors from the rostral migratory stream (RMS) display almost no $5 \mathrm{hmC}$ staining (arrows) as shown by high-power views of the respective framed boxes in A-D. I-L: High-power views of the respective framed boxes in $\mathrm{E}-\mathrm{H}$ showing two $5 \mathrm{hmC}$ and PCNA double-positive cells (arrowheads) while most other proliferative cells are $5 \mathrm{hmC}$-negative (arrows). M-T: Proliferative cells from the dorsomedian telencephalon (Dm) are $5 \mathrm{hmC}$-negative (arrows) as shown with high-power views of the respective framed boxes in M-P. Scale bar $=70 \mu \mathrm{m}$ for E-L; $140 \mu \mathrm{m}$ for A-D. 
compare it with zebrafish, we performed some experiments on Xenopus laevis. In larval and juvenile Xenopus, $5 \mathrm{hmC}$ was also widely detected throughout the brain, although proliferative cells (PCNA-positive) localized along the ventricular layers were consistently $5 \mathrm{hmC}$ negative, as shown in the diencephalon and the telencephalon (Fig. 4A-D1,I-L1, see arrows; th: thalamus; $\mathrm{mp}$ : medial pallium). Similar to what was observed in zebrafish, double immunohistochemistry for $5 \mathrm{hmC}$ and acetylated tubulin clearly showed that 5hmC-positive cells correspond to neurons (Fig. 4E-H1,M-P1). In contrast, cells lining the ventricles, previously shown to be radial glia and progenitor cells in Xenopus (Coumailleau et al., 2015), are 5hmC-negative and acetylated tubulinnegative (Fig. 4E-H1,M-P1).

Similar to what was observed in zebrafish, double immunohistochemistry for $5 \mathrm{hmC}$ and PCNA in Xenopus clearly showed that proliferative cells do not exhibit detectable levels of $5 \mathrm{hmC}$ (Fig. 4A-D1,I-L1).

\section{$5 \mathrm{hmC}$ mark increases during cortical neurogenesis in mouse}

Immunostaining on mouse brain sections revealed abundant 5hmC-positive nuclei in all forebrain structures examined, including the cortex, the hippocampus, the thalamus, the hypothalamus, and also the choroid plexus (data not shown). We next focused on the embryonic period associated with active neurogenesis. In the developing cortex, $5 \mathrm{hmC}$ staining was strongly detected at E14.5 in the cortical plate containing the earliest postmitotic neurons generated (Fig. 5A-C, arrows), while the intermediate and ventricular zones only displayed weakly $5 \mathrm{hmC}$-positive cells. More precisely, the $5 \mathrm{hmC}$ staining appeared to be slightly stronger in the intermediate zone (Fig. 5B,D). At E14.5, the ventricular zone is composed of actively dividing radial glial cells and other further committed progenitors, giving rise to newborns that initiate migration through the developing cortex. Double immunohistochemistry for PCNA and $5 \mathrm{hmC}$ performed during this neurogenic period clearly indicated that proliferative cells (PCNA-positive cells) are weakly positive for $5 \mathrm{hmC}$ (Fig. 5D-F). Conversely, especially in the intermediate zone (Fig. $5 \mathrm{D}-\mathrm{F}$, arrows) but also in the ventricular zone (arrowheads), the strongest $5 \mathrm{hmC}$-positive cells are PCNAnegative, suggesting that cell-cycle exit is accompanied by an enrichment of the $5 \mathrm{hmC}$ content in the newborn neurons. Accordingly, double immunohistochemistry for $5 \mathrm{hmC}$ and acetylated-tubulin showed that high $5 \mathrm{hmC}$ positive cells in the cortical plate correspond to neurons at E14.5 (data not shown) and at E18.5 (Fig. 5G). Taken together, these data show that neural progenitors exhibit low levels of $5 \mathrm{hmC}$ and that the neurogenesis and differentiation processes are accompanied by an enrichment of this epigenetic mark in newborn neurons. Similarly, in the dentate gyrus of the hippocampus that retains a neurogenic activity during the whole lifespan, proliferative cells at P7 do not express the $5 \mathrm{hmC}$ epigenetic mark (Fig. 5L-O, arrows). However, a few proliferative cells that weakly expressed PCNA were also $5 \mathrm{hmC}$-positive, possibly reflecting a transitional state (Fig. 5L-O, arrowheads).

Very interestingly, while $5 \mathrm{hmC}$ was mainly detected in differentiated neurons of the CP at E16.5 (Fig. 6A,G), $5 \mathrm{hmC}$ levels increased until E18.5 through the cortical layer during the differentiation process of neurons (Fig. $6 \mathrm{~A}, \mathrm{D}, \mathrm{G}, \mathrm{K})$. Indeed, $5 \mathrm{hmC}$ was mainly detected in the outer layers of the cerebral cortex at E16.5, while the SVZ/VZ was barely positive for $5 \mathrm{hmC}$ (Fig. 6A,G). In contrast, at E18.5, when cortical neurogenesis comes to an end and gliogenesis starts, $5 \mathrm{hmC}$-positive cells were more widely distributed throughout all cortical layers and also in the VZ/SVZ (Fig. 6D,K), although at lower levels. In parallel, $5 \mathrm{mC}$ was more widely distributed in the cortical layers at E16.5 compared to E18.5 (Fig. 6B,E,H,L). At E16.5 and E18.5, 5mC was widely distributed in the ventricular zone, whereas only a few cells were $5 \mathrm{mC}$-positive in the other cortical layers (Fig. $6 \mathrm{~B}, \mathrm{E})$. Hence, $5 \mathrm{hmC}$ levels increase progressively in the cortex over the neurogenic processes, while $5 \mathrm{mC}$ levels decreased in the cortical layer but were more strongly detected in the VZ/SVZ (Fig. 6). Such data suggest that $5 \mathrm{mC}$ could be partly converted into $5 \mathrm{hmC}$ during the process of neuronal maturation. To confirm this point, further studies are required.

We also decided to investigate $5 \mathrm{hmc}$ expression in the olfactory epithelium of adult mice and zebrafish, as this tissue produces new olfactory neurons. By performing 5hmc and PCNA double immunohistochemistry, we observed that only a few cells are $5 \mathrm{hmc}$-positive in the olfactory epithelium of zebrafish (Fig. 7), while more cells appear to display this epigenetic mark in the olfactory epithelium of mouse (Fig. 7). However, 5hmc immunostainings of olfactory epithelium in mouse did not always appear consistent with more or less $5 \mathrm{hmc}-$ labeling (data not shown).

\section{$5 \mathrm{hmC}$ accumulates in MeCP2- and H3K4me2-enriched nuclear foci in mouse neurons}

Interestingly, the high-magnification confocal image of neuron nuclei revealed that $5 \mathrm{hmC}$ accumulates in nuclear foci, suggesting that regulatory regions bearing this epigenetic mark are not randomly distributed in the 

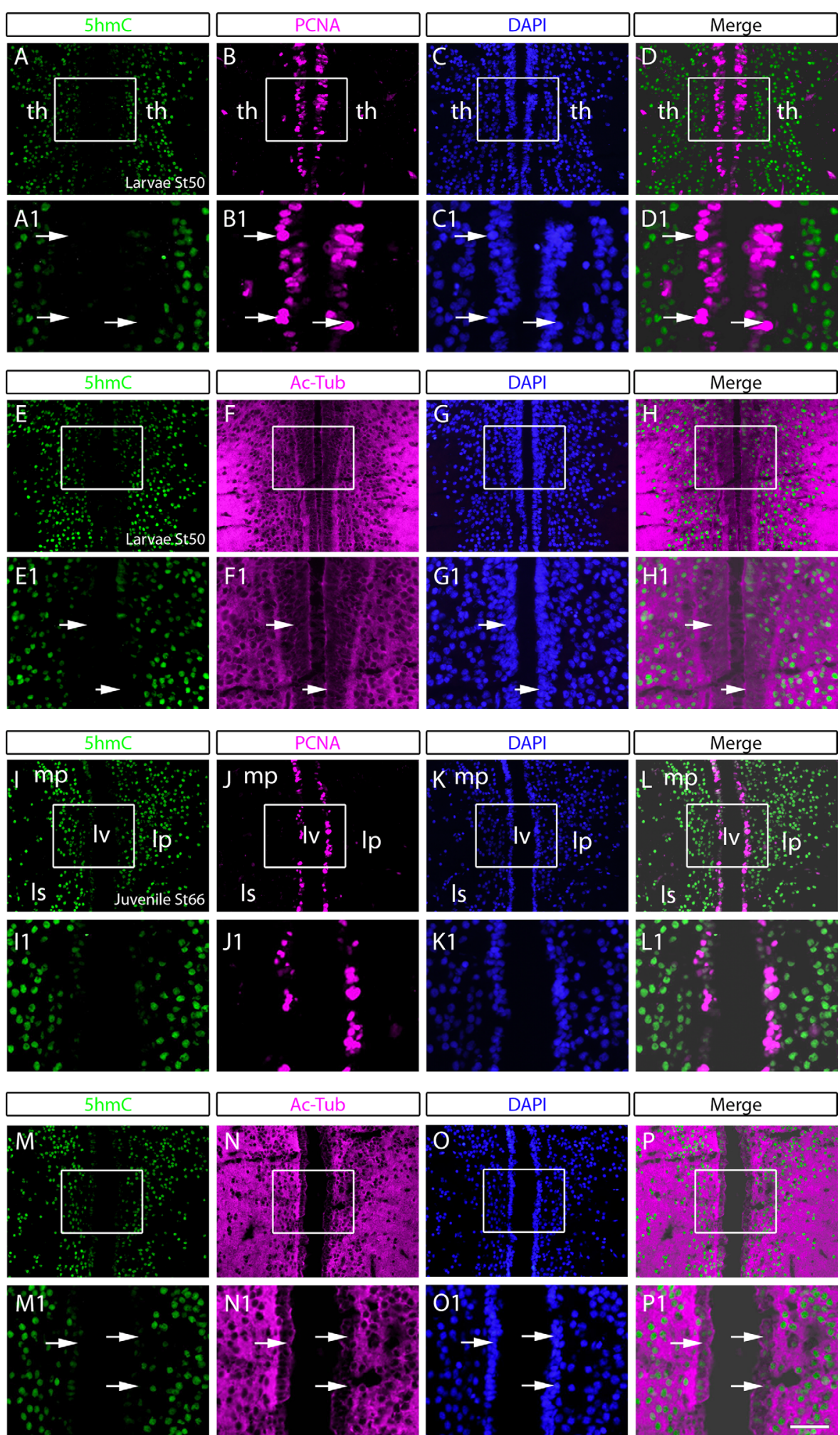

Figure 4. $5 \mathrm{hmC}$-expressing cells correspond to neurons but not to proliferative cells at larval (St50) and juvenile (St66) stages in Xenopus. A-D1 and I-L1: 5hmC and PCNA double immunohistochemistry on the larval (A-D1; thalamic area) and juvenile (I-L1; dorsal telencephalic area) brains showing that proliferative cells from the ventricular layer do not display the $5 \mathrm{hmC}$ mark at larval (A-D1) or juvenile stages (I-L1). A1-D1 and I1-L1: High-power views of the respective framed boxes in A-D and I-L. Arrows point to 5hmC-negative proliferative cells. E-H1 and M-P1: $5 \mathrm{hmC}$ and acetylated tubulin double immunohistochemistry on the larval (E-H1; thalamic area: th) and juvenile (M-P1; dorsal telencephalic area) brains showing that $5 \mathrm{hmC}$-expressing cells mainly correspond to neurons as shown at larval (E-H1) and juvenile stages (M-P1). E1-H1 and M1-P1: High-power views of the respective framed boxes in E-H and M-P. Arrows point to ventricular cells that do not exhibit acetylated tubulin labeling. Ip, lateral pallium; Is, lateral septum; Iv, lateral ventricle; mp, medial pallium, th: thalamus. Scale bar $=90 \mu \mathrm{m}$ for A-D,E-H,I-L,M-P; $35 \mu \mathrm{m}$ for A1-D1,E1-H1,I1-L1,M1-P1. 

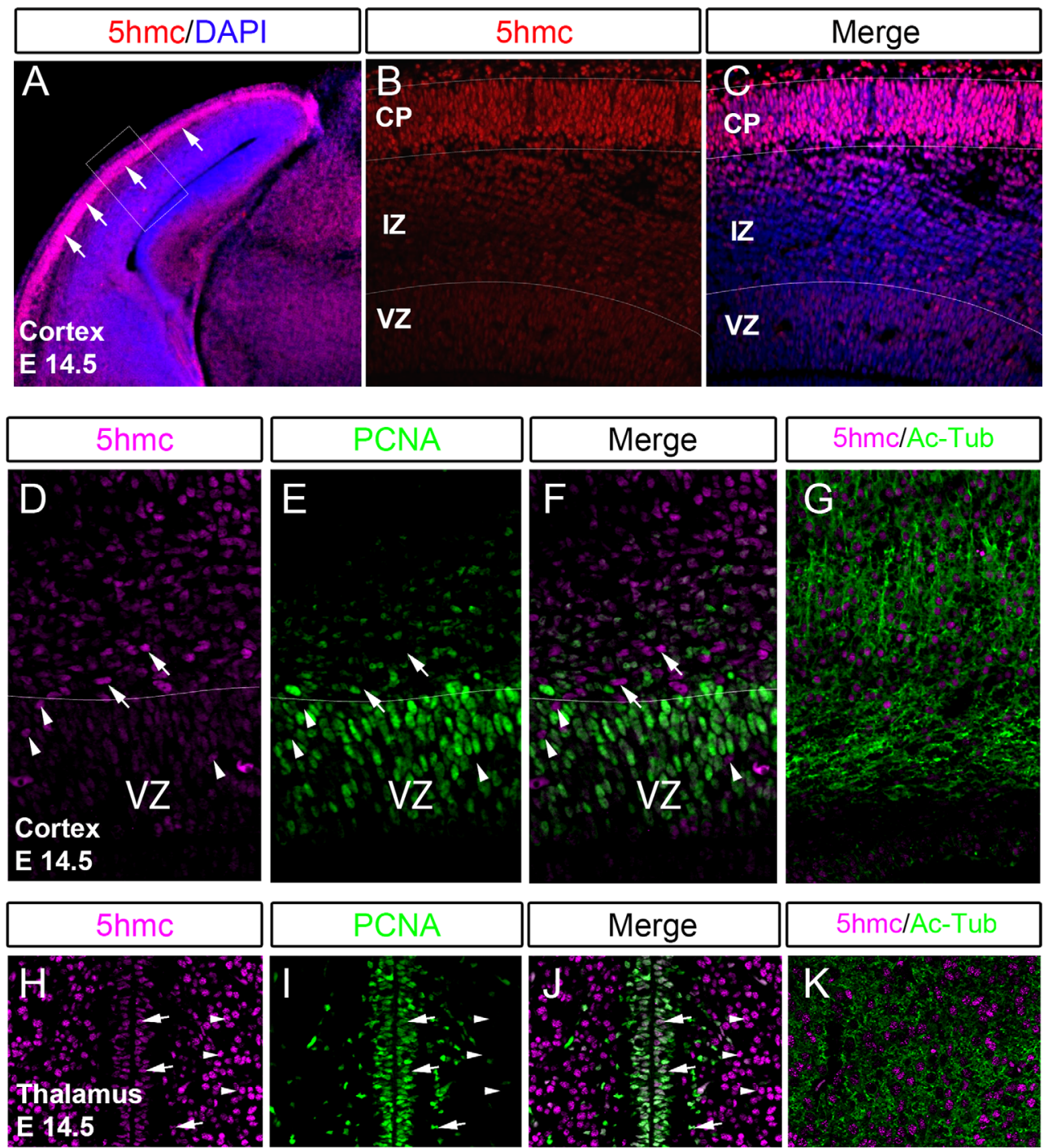

5hmc/Ac-Tub
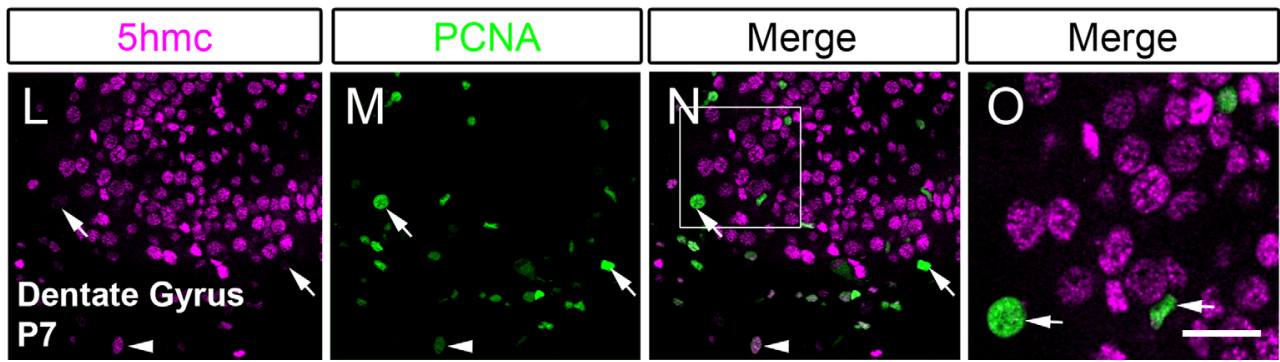

Figure 5. Most proliferative cells from neurogenic areas are 5hmC-negative during embryogenesis and after birth. A-C: $5 \mathrm{hmC}$ immunohistochemistry (red) with cell nuclei staining (blue) during cerebral corticogenesis at E14.5. Note that $5 \mathrm{hmC}$ is mainly distributed in the cortical plate (CP, arrows) composed of differentiated neurons while the intermediate (IZ) and ventricular (VZ) zones display no, or only few and weak 5hmC-positive cells. D-F: $5 \mathrm{hmC}$ (magenta) and PCNA (green) immunohistochemistry showing that during the neurogenic period at E14.5 neural progenitors in proliferation from the VZ are mainly $5 \mathrm{hmC}$-negative. Arrowheads point to $5 \mathrm{hmC}$-positive and PCNA-negative cells in the VZ, while arrows point to $5 \mathrm{hmC}$-positive and PCNA-negative cells in the IZ. At E14.5, most 5hmC-positive cells from the cortical layers correspond to acetylated tubulin neurons as shown in G. H-J: $5 \mathrm{hmC}$ (magenta) and PCNA (green) immunohistochemistry showing that at the end of the neurogenesis and at the onset of gliogenesis in the thalamus (E14.5), PCNA-positive cells are weakly $5 \mathrm{hmC}$ positive (arrows) compared to parenchymal cells strongly expressing the $5 \mathrm{hmC}$ mark (arrowheads). At E14.5, most 5hmC-positive cells from the diencephalon correspond to acetylated tubulin neurons as shown in K. L-O: $5 \mathrm{hmC}$ (magenta) and PCNA (green) immunohistochemistry showing that in the dentate gyrus of the hippocampus, a region retaining neurogenic activity during the entire lifespan, most PCNA-positive cells are 5hmC-negative (arrows) at P7. The 0 picture corresponds to a high-power view of the framed box in N. Scale bar $=14 \mu \mathrm{m}$ for $0 ; 35 \mu \mathrm{m}$ for L-N; $40 \mu \mathrm{m}$ for D-G; $56 \mu \mathrm{m}$ for $\mathrm{H}-\mathrm{K} ; 112 \mu \mathrm{m}$ for B,C. 

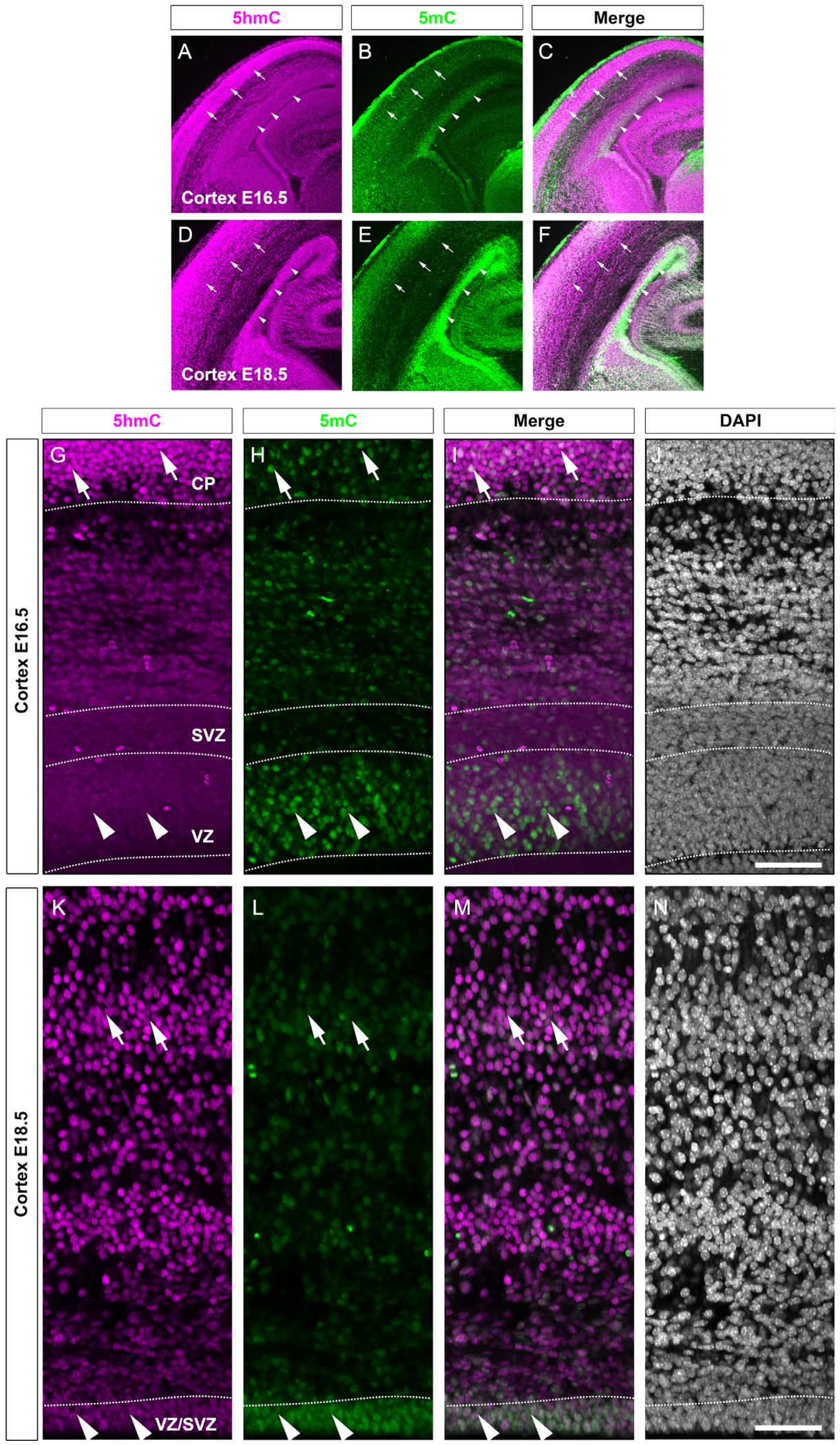

Figure 6. $5 \mathrm{mC}$ and $5 \mathrm{hmC}$ distribution in the cortex of developing mouse at E16.5 and E18.5. A-F: $5 \mathrm{hmC}$ (magenta) and $5 \mathrm{mC}$ (green) immunohistochemistry during cerebral corticogenesis at E16.5 and E18.5. G-J: $5 \mathrm{hmC}$ (magenta) and $5 \mathrm{mC}$ (green) distribution in the cortical layer at E16.5 with cell nuclei staining (blue). Most 5hmC-positive cells are detected in the cortical plate (CP) and only a few cells are detected in the other cortical layers, including the ventricular and subventricular layers (VZ and SVZ, respectively). In contrast, $5 \mathrm{mC}$ positive cells are more widely distributed through the cortical layer and are notably detected in the VZ. Arrows point to $5 \mathrm{hmC}$ and $5 \mathrm{mC}$ double-positive cells in the $\mathrm{CP}$, while arrowheads point to $5 \mathrm{mC}$-positive and $5 \mathrm{hmC}$-negative cells in the VZ. $\mathrm{K}-\mathrm{N}$ : $5 \mathrm{hmC}$ (magenta) and $5 \mathrm{mC}$ (green) distribution in the cortical layer at E18.5 with cell nuclei staining (blue). In contrast to E16.5, 5hmC-positive cells are more widely detected through the cortical layers out of the CP (arrows). Cells from the VZ/SVZ also display a weak 5 hmC-positive staining (arrowheads). Less $5 \mathrm{mC}$-positive cells are detected through the cortical layers, but numerous $5 \mathrm{mC}$ labeled cells are detected in the VZ/ SVZ. Scale bar $=64 \mu \mathrm{m}$ G-N; $500 \mu \mathrm{m}$ for A-F. 

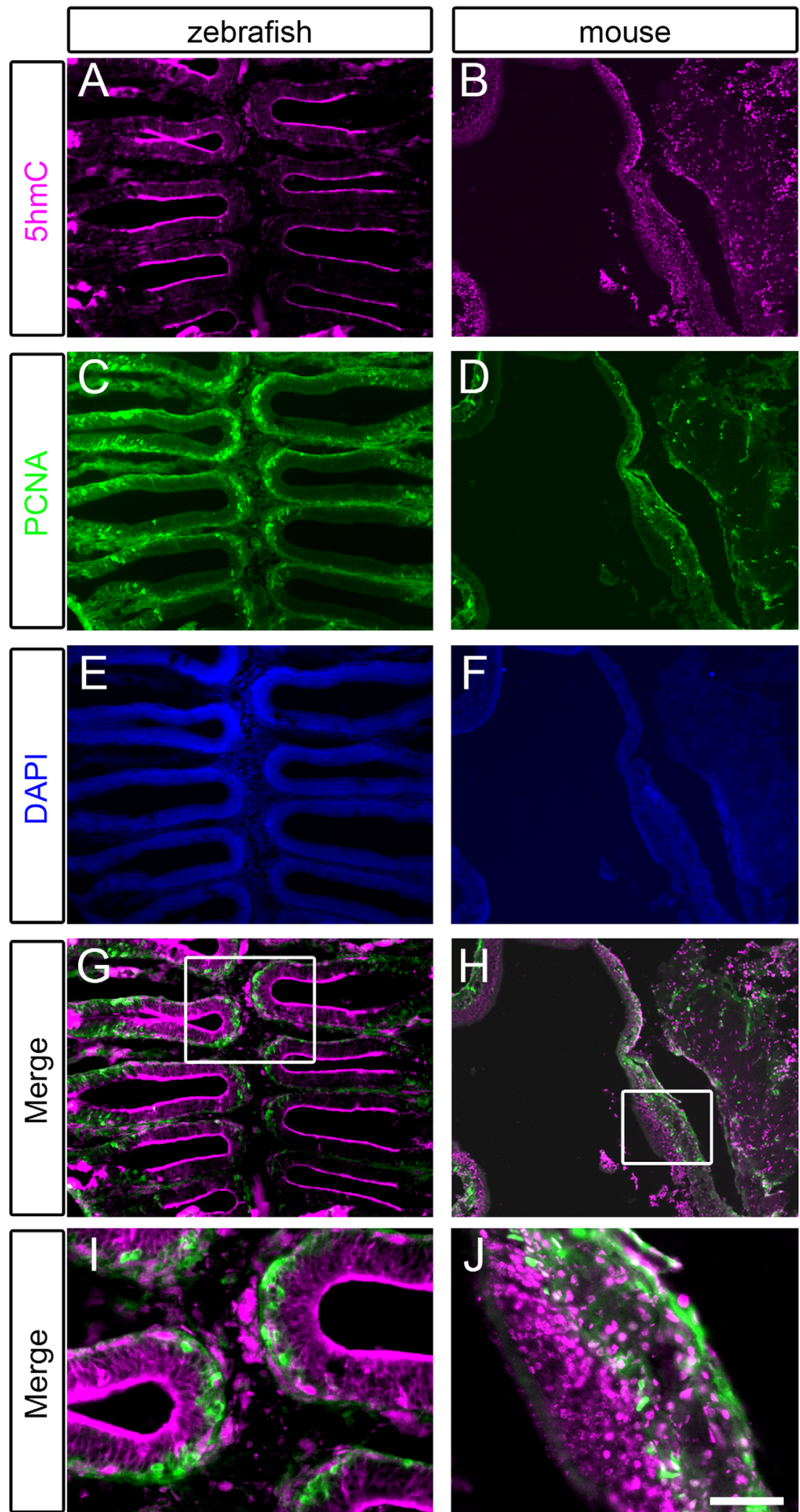

Figure 7. $5 \mathrm{hmC}$ distribution in the olfactory epithelium of adult zebrafish and mouse. In zebrafish, only a few cells are $5 \mathrm{hmc}$-positive (magenta) compared to mouse. However, we noticed that $5 \mathrm{hmc}$ staining in the olfactory epithelium of mouse was not consistent from one experiment to another. PCNA immunohistochemistry (green) shows that most proliferative cells do not express 5hmc. Note that in zebrafish a presumably artifactual staining is observed at the ciliary layer of the epithelium and does not correspond to nuclear labeling. Scale bar $=210 \mu \mathrm{m}$ for A,C,E,G; $75 \mu \mathrm{m}$ for I; $180 \mu \mathrm{m}$ for B,D,F,H; $70 \mu \mathrm{m}$ for J. 

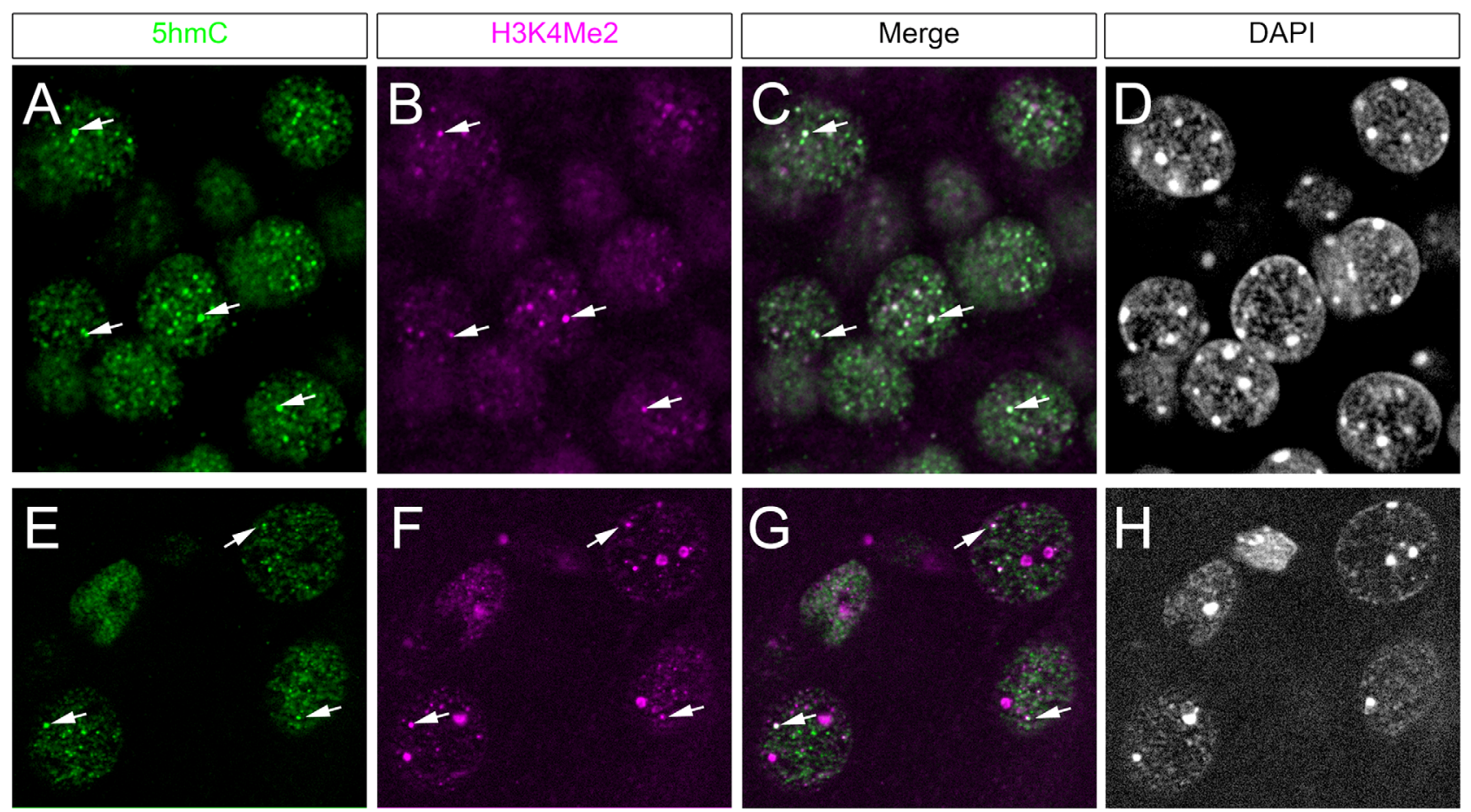

Figure 8. $5 \mathrm{hmC}$ colocalization with $\mathrm{H} 3 \mathrm{~K} 4 \mathrm{me} 2$ and MeCP2. A-H: $5 \mathrm{hmC}$ (green), H3K4me2 (magenta) and DAPI (white) staining in cortical cells showing $5 \mathrm{hmC}$ colocalization with H3K4Me2 (arrows). D-H: DAPI (white) staining in cortical cells showing few $5 \mathrm{hmC}$ co-localization with MeCP2 (arrows).

nuclear space (Fig. 8A,E). In mouse, an association of $5 \mathrm{hmC}$ with $\mathrm{H} 3 \mathrm{~K} 4 \mathrm{me} 2$, a mark of active chromatin found at enhancers, has been previously demonstrated genome-wide (Etchegaray et al., 2015), and methylCpG-binding protein 2 (MeCP2) has been shown to be the major $5 \mathrm{hmC}$-binding protein in the brain (Mellen et al., 2012). We consequently decided to investigate colocalization of these factors with $5 \mathrm{hmC}$ in the mouse brain. In all brain structures examined, numerous genomic regions with high $5 \mathrm{hmC}$ signal were found to be colocalized with H3K4me2 in nuclear foci (Fig. 8A-D). Similarly, a fraction of $5 \mathrm{hmC}$ foci appeared to be associated with MeCP2 in vivo (Fig. $8 \mathrm{E}-\mathrm{H}$ ). This is consistent with the proposed role of MeCP2 as a $5 \mathrm{hmC}$ reader (Mellen et al., 2012; Spuijt et al., 2013).

\section{Tet expression dynamics and regional distribution during mouse corticogenesis}

We finally decided to investigate the expression of the enzymes catalyzing the conversion of $5 \mathrm{mC}$ to $5 \mathrm{hmC}$ during mouse corticogenesis in order to better understand the links between $5 \mathrm{hmC}$ epigenetic mark increase and the expression of their synthesizing enzymes. The oxidative conversion of $5 \mathrm{mC}$ to $5 \mathrm{hmC}$ is catalyzed by the Tet enzyme family, which comprises three members in mouse (mTet1, mTet2, and mTet3). Given the increase in $5 \mathrm{hmC}$ levels during cortical neurogenesis, we next investigated expression of Tet enzymes by qPCR and in situ hybridization at different stages of embryogenesis. QPCR experiments revealed that $m T e t 1$ and $m T e t 2$ expression tended to increase during the peak of cortical neurogenesis, from E12 to E16 (Fig. 9, upper panel), while mTet3 expression appeared relatively stable. In all experiments, mTet1 was expressed lower than other members, whereas mTet3 displayed the strongest expression (Fig. 9, upper panel). Interestingly, a sharp decrease in $m T e t 1 / 2 / 3$ expression occurred at the end of cerebral corticogenesis (E18), before levels increased again at postnatal day 2 (Fig. 9, upper panel). Our fluorescent in situ hybridization at E18 on cerebral cortex confirmed mTet expression throughout the cortical layers, while no signal was detected with sense probes (Figs. 9A-C1, 10). Such data correlate with the strong distribution of $5 \mathrm{hmc}$ in the cortical layers at E18/E18.5, as shown in Figure 6. Consistent with qPCR data, mTet1 seemed less expressed and mTet3 displayed the strongest expression. In addition, mTet2 was mainly expressed in the outer cortical layers, while mTet 3 was more broadly expressed. We also observed mTet 3 expression in the 

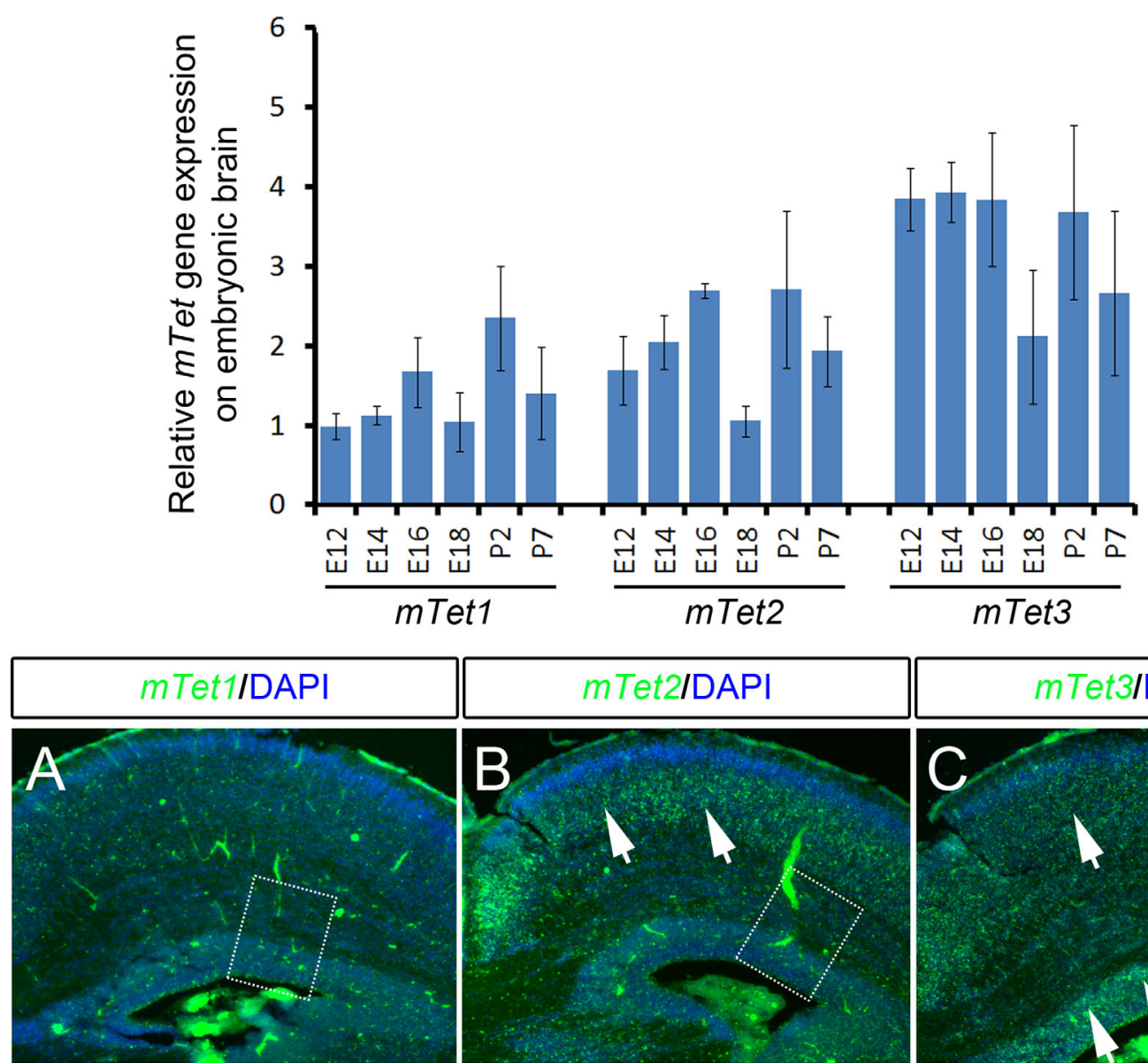

mTet3IDAPI
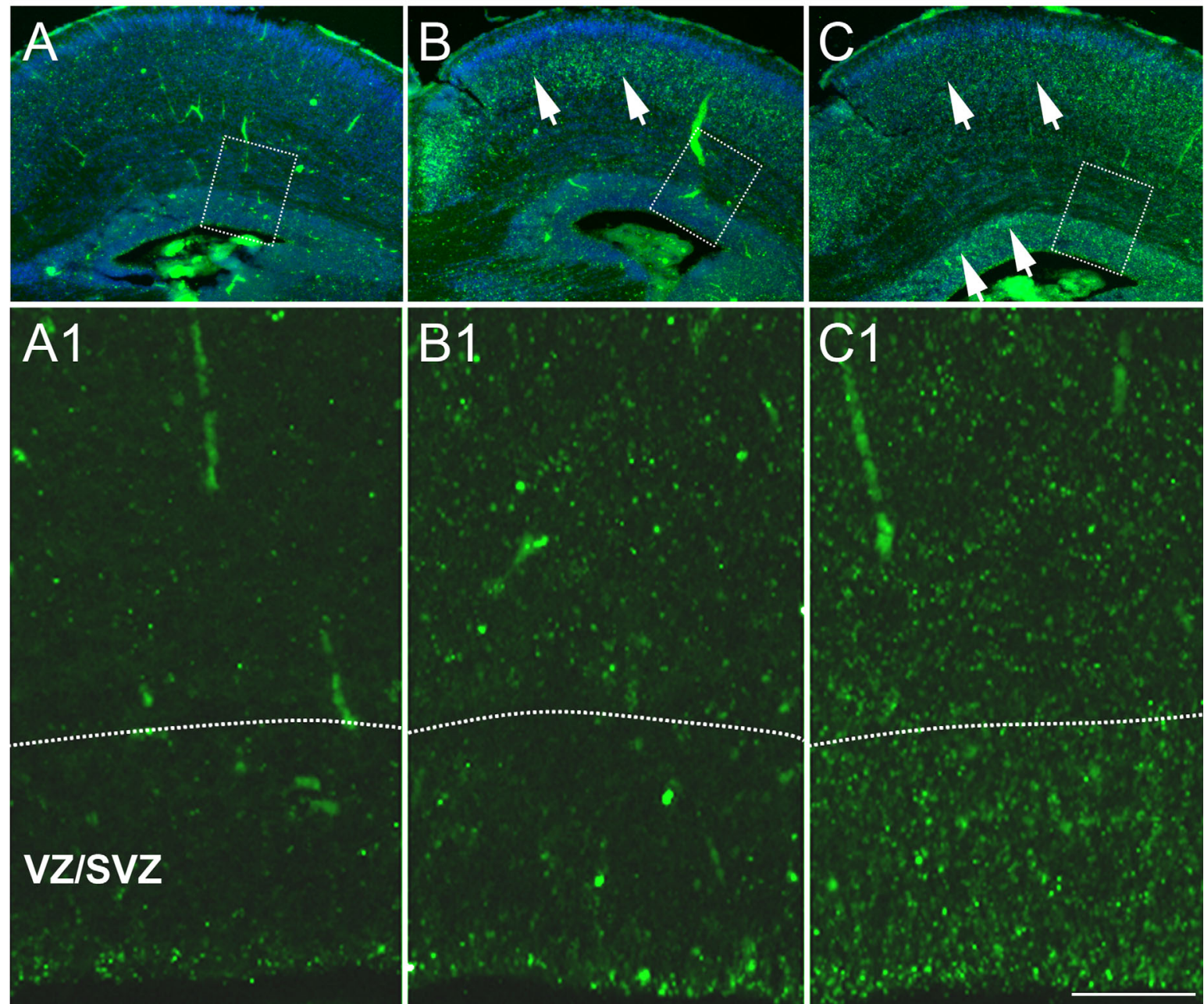

Figure 9. Mouse Tet (mTet) expression in the brain during development and after birth. Top panel: qPCR expression of $m$ Tet $1 / 2 / 3$ through the developing brain of mouse from E12 to P7. mTet 1 is the less expressed member and mTet 3 the more expressed one. A global mTet expression decrease is noticed at E18. Bottom panel: $m$ Tet1/2/3 (A-C) in situ hybridization on the cerebral cortex at E18. mTet1 is only weakly expressed. mTet2 is mainly expressed in the outer cortical layer, while mTet 3 is more widely expressed and notably in the VZ/ SVZ. A1-C1: High-power views of the respective framed boxes A-C. Scale bar $=170 \mu \mathrm{m}$ for A1-C 1; $2.5 \mathrm{~mm}$ for A-C. 

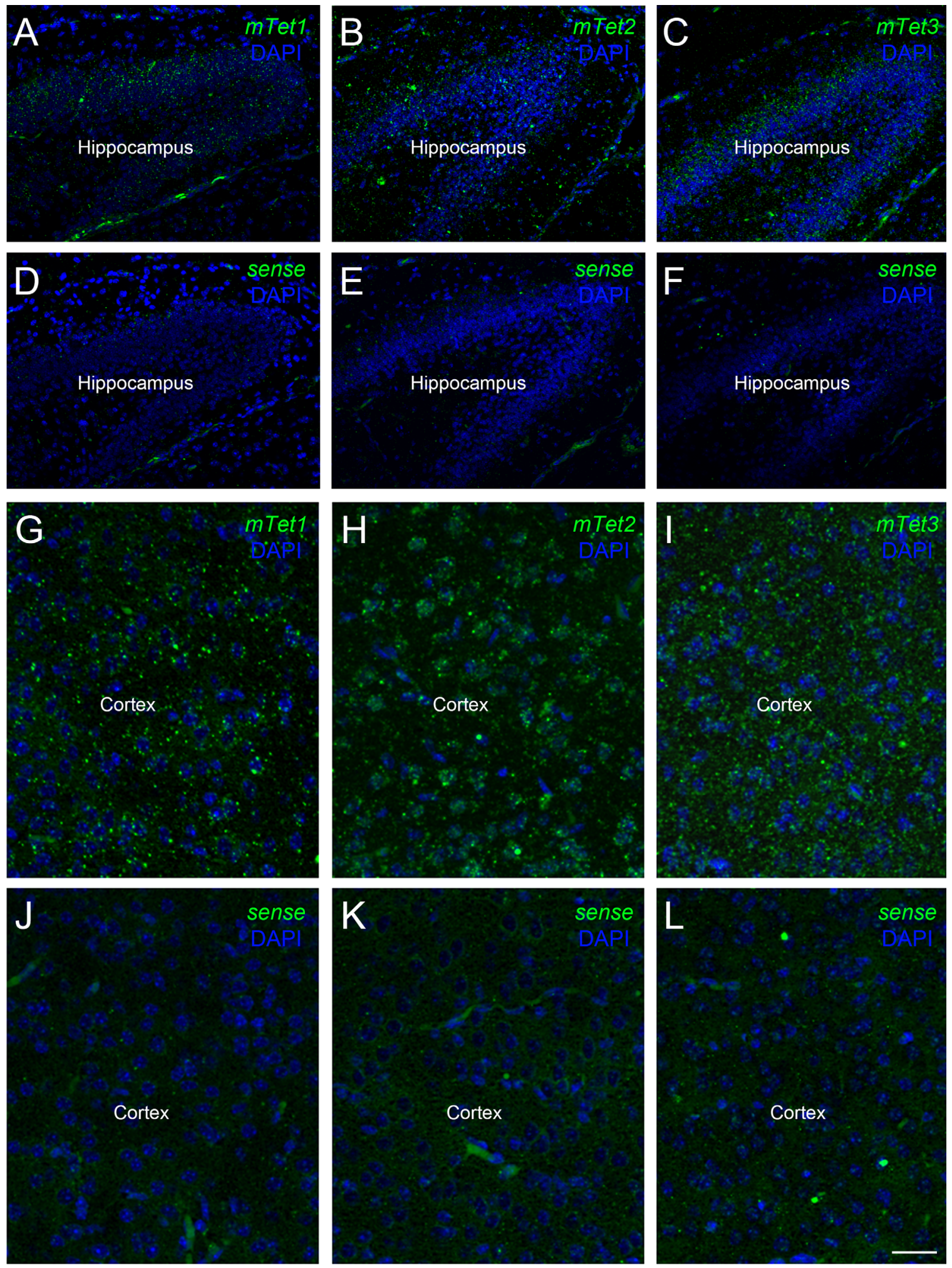

Figure 10. mTet expression in the cortex and the hippocampus at P7. A-F: $m$ Tet1/2/3 in situ hybridization with antisense (A-C) probes show a wide $m$ Tet RNA expression in the hippocampus, while no staining was observed with sense probes (D-F). G-L: $m$ Tet $1 / 2 / 3$ in situ hybridization with antisense $(\mathrm{G}-\mathrm{I})$ probes show a wide mTet RNA expression in the cortex, while no staining was observed with sense probes (J-L). Scale bar $=28 \mu \mathrm{m}$ for G-L; $56 \mu \mathrm{m}$ for A-F. 
VZ/SVZ at around E18 when the $5 \mathrm{hmc}$ epigenetic mark starts to appear (Figs. 6D,K, 9). Such data suggest that Tet3 could be broadly responsible for the oxidation of $5 \mathrm{mC}$ to $5 \mathrm{hmC}$ in the cortex, although Tet2 might have a more localized function. Interestingly, mTet1/2/3 were still expressed in the hippocampus and the cortex at P7, as shown in Figure 10A-C,G-I). No signal was observed with the respective sense probes (Fig. 10DF,J-L).

\section{DISCUSSION}

Epigenetic factors such as DNA methylation and hydroxymethylation are mechanisms playing key roles in the regulation of gene expression and cellular functions (Cheng et al., 2015b). In a way similar to histone modifications, DNA methylation provides a fundamental epigenetic control mechanism absolutely required for the proper development of embryos by regulating, for example, genomic imprinting and by repressing retrotransposons expression (Cheng et al., 2015b; Meng et al., 2015). Tet proteins can oxidize $5 \mathrm{mC}$ into $5 \mathrm{hmC}$ (Ito et al., 2010). Interestingly, Tet proteins as well as $5 \mathrm{mC}$ and $5 \mathrm{hmC}$ epigenetic marks have been shown to be involved in ES cell self-renewal and differentiation, and consequently to play key roles in stem cell activity (Ito et al., 2010; Ficz et al., 2011; Pastor et al., 2011; Cheng et al., 2015b). Indeed, Tet1 and Tet2 knockdown results in a downregulation of a number of genes including pluripotency-related ones (Ficz et al., 2011). In mammals, $5 \mathrm{hmC}$ has been previously described as being strongly expressed in neurons (Chen et al., 2012; Hahn et al., 2013; Kraus et al., 2015; Meng et al., 2015; Zheng et al., 2015). Numerous studies described the presence of $5 \mathrm{hmC}$ in brain cells, but they mainly focus at the genomic level. Consequently, data are lacking concerning $5 \mathrm{hmC}$ distribution during neurogenesis in mammals.

In this work we have shown that levels of $5 \mathrm{hmC}$ are particularly elevated in differentiated neurons in adult zebrafish and larva and juvenile Xenopus, similar to what was previously demonstrated in mammals (Jin et al., 2011; Chen et al., 2012; Hahn et al., 2013; Kraus et al., 2015; Zheng et al., 2015). In addition, we provide evidence that radial glial cells lining the ventricular surface and behaving as neural stem cells do not (or only barely) show detectable levels of $5 \mathrm{hmC}$. We also report similar findings in mouse during cerebral corticogenesis. Indeed, at E14.5, $5 \mathrm{hmC}$ is mainly detected in differentiated neurons of the cortical plate, and its levels increase until E18.5 throughout all cortical layers. However, from E14.5 to E16.5, $5 \mathrm{hmC}$ is barely detected in the SVZ/VZ that is composed of neural progenitors including radial glia. At E18.5, a time corresponding to the end of cortical neurogenesis and to the onset of cortical gliogenesis, $5 \mathrm{hmC}$-positive cells are more widely distributed throughout all cortical layers and notably at low levels in the VZ/SVZ, suggesting that, in gliogenic progenitors, $5 \mathrm{mC}$ oxidation tends to increase at the end of the neurogenic period. In zebrafish, Xenopus, and mouse, $5 \mathrm{hmC}$ seems to be weakly expressed by neural progenitors from ventricular layers, while differentiated neurons strongly express this mark. Given that adult zebrafish are known for conserving throughout life features of the developing rodent brain (i.e., radial glial cells, intense neurogenic activity) (Lindsey and Tropepe, 2006; Diotel et al., 2010a; Grandel and Brand, 2013), it could explain why the ventricular zone does not show detectable levels of $5 \mathrm{hmC}$ in zebrafish, while $5 \mathrm{hmC}$-positive cells appear throughout the ventricular and subventricular zones at the end of cortical neurogenesis in mouse. In addition, double $5 \mathrm{hmC}$ and PCNA immunohistochemistry further confirmed that $5 \mathrm{hmC}$ is not detected in proliferative cells, as shown here in zebrafish, Xenopus, and mouse (Figs. 3-5), notably in the whole ventricular zone, including the RMS in zebrafish. Indeed, along the ventricular layers in the brain of larval and juvenile Xenopus, layers where radial glial cells were previously identified (D'Amico et al., 2011, 2013), proliferative cells do not express the $5 \mathrm{hmC}$ mark, as shown in Figure 4. Only very few PCNA-positive cells were identified as $5 \mathrm{hmC}$-positive in zebrafish and mouse, demonstrating conserved features for $5 \mathrm{hmC}$ distribution between fish, amphibians, and mammals. In addition, in the dentate gyrus of the hippocampus that retains a neurogenic activity in mouse during their lifespan, similar observations were made only at P7 (Fig. 5). Taken together, our results show that neural progenitors (quiescent ones and proliferative ones) appear to not or only weakly display $5 \mathrm{hmC}$ during neurogenesis in the three species studied. This is particularly interesting given the fact that epigenetic regulators could modulate the spatial-temporal expression of key genes involved in proliferation and differentiation of neural stem cells during embryogenesis and adulthood (Ma et al., 2010; Yao and Jin, 2014; Cheng et al., 2015b).

We also demonstrate here that mTet expression slightly increases in the brain during embryonic development in mouse (Fig. 6) and that mTet3 was more strongly expressed, as shown by qPCR and in situ hybridization, in the cerebral cortex. Notably, a wide distribution of mTet3-expressing cells was observed in the VZ/SVZ at E18.5, suggesting mTet3 expression by progenitors during the gliogenic period. Such an expression is in agreement with $5 \mathrm{hmC}$ appearance at this 
stage in the VZ/SVZ. Similarly, in the cortex and the dentate gyrus at P7, mTet expression is detected by in situ hybridization. In zebrafish, Tet $1 / 2 / 3$ transcripts are weakly expressed or undetectable in embryos before the onset of organogenesis (Almeida et al., 2012; Armant et al., 2013), explaining that $5 \mathrm{hmC}$ signal was first observed in 10-somite stage embryos, and increased progressively throughout development, while $5 \mathrm{mC}$ signal was observed in all stages (Almeida et al., 2012). RNAseq data also demonstrated Tet $1 / 2 / 3$ expression in the telencephalon of adult zebrafish (Armant et al., 2013). However, data are lacking concerning the spatial distribution of these enzymes. In Xenopus, there is little information concerning Tet expression; however, $\mathrm{Xu}$ et al. (2012) documented a potential role of Tet3 in early eye and neural development. We also showed that $5 \mathrm{hmC}$ partially colocalizes with $\mathrm{H} 3 \mathrm{~K} 4 \mathrm{me} 2$ and MeCP2 in mouse cerebral cortex. These data further reinforce previous observations showing: 1) that MeCP2 binds to $5 \mathrm{hmC}$-enriched active genes and accessible chromatin in the nervous system, supporting the idea that MeCP2 and $5 \mathrm{hmC}$ play roles in the regulation of chromatin structure and gene expression (Mellen et al., 2012), and 2) that $5 \mathrm{hmC}$ progressively colocalizes with MBD3 and recruits $\mathrm{H} 3 \mathrm{~K} 4 \mathrm{me} 2$ in euchromatin regions (Chen et al., 2014). These data further argue in favor of a role of $5 \mathrm{hmC}$ in the regulation of gene expression and chromatin structure. Interestingly, deregulation of $5 \mathrm{hmC}$ levels is emerging as a potential cause of neurodegenerative diseases (Coppieters and Dragunow, 2011; Irier and Jin, 2012; Al-Mahdawi et al., 2014; Coppieters et al., 2014; Cheng et al., 2015a). For instance, a decrease in $5 \mathrm{hmC}$ levels was reported in the hippocampus and the brain of Alzheimer's disease (AD), while other studies showed the opposite tendency (Chouliaras et al., 2013; Al-Mahdawi et al., 2014). Given the data obtained in our study, it could be logical that a decrease in $5 \mathrm{hmc}$ level is observed in the hippocampus of $A D$ people given that neurogenesis should be decreased and neurodegeneration increased. However, the discrepancies observed between these studies could result from different brain areas studies, stages of $A D$, and different quantification techniques. Accumulating data also show modulation of $5 \mathrm{mC}$ and $5 \mathrm{hmC}$ levels in other neurodegenerative diseases such as amyotrophic lateral sclerosis, fragile $\mathrm{X}$-associated tremor/ataxia syndrome, Friedreich ataxia, Huntington's disease, and also Parkinson's disease (Al-Mahdawi et al., 2014).

In conclusion, the present study provides further information regarding the distribution of the $5 \mathrm{hmC}$ epigenetic mark in the brain of fish, developing amphibians, and developing mouse. We show that $5 \mathrm{hmC}$ is not detected in radial progenitors and increases with neuronal differentiation, as shown in cortical development. Given that actinopterygians and sarcopterygians diverged some 450 million years ago, this study also provides strong evidence that the cell-specific and dynamics of $5 \mathrm{hmC}$ apposition are evolutionarily conserved, suggesting that $5 \mathrm{hmC}$ functions during neurogenesis were already acquired in early vertebrates. Taken together, these data support the idea that zebrafish could be an interesting model for investigating the potential functions of $5 \mathrm{hmC}$ in neuronal fate and differentiation in vivo.

\section{ACKNOWLEDGMENT}

We thank Imade Ait Arsa for help with mouse.

\section{CONFLICT OF INTEREST}

None of the authors have any competing interests.

\section{AUTHOR CONTRIBUTIONS}

ND, YM, PC, AS, GS, and OK designed the experiments. ND, YM, PC, GS, and OK supervised the work. ND, YM, PC, MMG conducted the experiments. ND, YM, PC, GS, and OK analyzed the data and wrote the article All authors read and approved the final article.

\section{LITERATURE CITED}

Adolf B, Chapouton P, Lam CS, Topp S, Tannhauser B, Strähle U, Götz M, Bally-Cuif L. 2006. Conserved and acquired features of adult neurogenesis in the zebrafish telencephalon. Dev Biol 295:278-293.

Al-Mahdawi S, Virmouni SA, Pook MA. 2014. The emerging role of 5-hydroxymethylcytosine in neurodegenerative diseases. Front Neurosci 8:397.

Almeida RD, Loose M, Sottile V, Matsa E, Denning C, Young L, Johnson AD, Gering M, Ruzov A. 2012. 5-hydroxymethyl-cytosine enrichment of non-committed cells is not a universal feature of vertebrate development. Epigenetics 7:383-389.

Armant $\mathrm{O}$, März M, Schmidt R, Ferg $M$, Diotel N, Ertzer R, Bryne JC, Yang L, Baader I, Reischl M, Legradi J, Mikut $R$, Stemple D, ljcken W, van $\operatorname{der}$ Sloot A, Lenhard B, Strähle U, Rastegar S. 2013. Genome-wide, whole mount in situ analysis of transcriptional regulators in zebrafish embryos. Dev Biol 380:351-362.

Baranzini SE, Mudge J, van Velkinburgh JC, Khankhanian P, Khrebtukova I, Miller NA, Zhang L, Farmer AD, Bell CJ, Kim RW, May GD, Woodward JE, Caillier SJ, McElroy JP, Gomez R, Pando MJ, Clendenen LE, Ganusova EE, Schilkey FD, Ramaraj T, Khan OA, Huntley JJ, Luo S, Kwok PY, Wu TD, Schroth GP, Oksenberg JR, Hauser SL, Kingsmore SF. 2010. Genome, epigenome and RNA sequences of monozygotic twins discordant for multiple sclerosis. Nature 464:1351-1356.

Braun SM, Jessberger S. 2014. Adult neurogenesis: mechanisms and functional significance. Development 141: 1983-1986.

Chapouton P, Jagasia R, Bally-Cuif L. 2007. Adult neurogenesis in non-mammalian vertebrates. BioEssays 29:745757. 
Chen H, Dzitoyeva S, Manev H. 2012. Effect of aging on 5hydroxymethylcytosine in the mouse hippocampus. Restor Neurol Neurosci 30:237-245.

Chen Y, Damayanti NP, Irudayaraj J, Dunn K, Zhou FC. 2014. Diversity of two forms of DNA methylation in the brain. Front Genet 5:46.

Cheng Y, Bernstein A, Chen D, Jin P. 2015a. 5-Hydroxymethylcytosine: A new player in brain disorders? Exp Neurol 268:3-9.

Cheng $\mathrm{Y}$, Xie N, Jin P, Wang T. 2015b. DNA methylation and hydroxymethylation in stem cells. Cell Biochem Funct 33:161-173.

Chouliaras L, Mastroeni D, Delvaux E, Grover A, Kenis G, Hof PR, Steinbusch HW, Coleman PD, Rutten BP, van den Hove DL. 2013. Consistent decrease in global DNA methylation and hydroxymethylation in the hippocampus of Alzheimer's disease patients. Neurobiol Aging 34: 2091-2099.

Coen L, Le Blay K, Rowe I, Demeneix BA. 2007. Caspase-9 regulates apoptosis/proliferation balance during metamorphic brain remodeling in Xenopus. Proc Natl Acad Sci U S A 104:8502-8507.

Coppieters N, Dragunow M. 2011. Epigenetics in Alzheimer's disease: a focus on DNA modifications. Curr Pharm Des 17:3398-3412.

Coppieters N, Dieriks BV, Lill C, Faull RL, Curtis MA, Dragunow M. 2014. Global changes in DNA methylation and hydroxymethylation in Alzheimer's disease human brain. Neurobiol Aging 35:1334-1344.

Coumailleau P, Kah O. 2014. Cyp19a1 (Aromatase) expression in the Xenopus brain at different developmental stages. J Neuroendocrinol 26:226-236.

Coumailleau P, Pellegrini E, Adrio F, Diotel N, Cano-Nicolau J, Nasri A, Vaillant C, Kah O. 2015. Aromatase, estrogen receptors and brain development in fish and amphibians. Biochim Biophys Acta 1849:152-162.

D’Amico LA, Boujard D, Coumailleau P. 2011. Proliferation, migration and differentiation in juvenile and adult Xenopus laevis brains. Brain Res 1405:31-48.

D'Amico LA, Boujard D, Coumailleau P. 2013. The neurogenic factor NeuroD1 is expressed in post-mitotic cells during juvenile and adult Xenopus neurogenesis and not in progenitor or radial glial cells. PLoS One 8:e66487.

Denver RJ, Hu F, Scanlan TS, Furlow JD. 2009. Thyroid hormone receptor subtype specificity for hormonedependent neurogenesis in Xenopus laevis. Dev Biol 326:155-168.

Dinarello CA. 2012. Keep up the heat on IL-1. Blood 120: 2538-2539.

Diotel N, Le Page Y, Mouriec K, Tong SK, Pellegrini E, Vaillant C, Anglade I, Brion F, Pakdel F, Chung BC, Kah $\mathrm{O}$. 2010a. Aromatase in the brain of teleost fish: expression, regulation and putative functions. Front Neuroendocrinol 31:172-192.

Diotel N, Vaillant C, Gueguen MM, Mironov S, Anglade I, Servili A, Pellegrini E, Kah O. 2010b. Cxcr4 and Cxcl12 expression in radial glial cells of the brain of adult zebrafish. J Comp Neurol 518:4855-4876.

Diotel N, Vaillant C, Gabbero C, Mironov S, Fostier A, Gueguen MM, Anglade I, Kah O, Pellegrini E. 2013. Effects of estradiol in adult neurogenesis and brain repair in zebrafish. Horm Behav 63:193-207.

Diotel N, Rodriguez Viales R, Armant O, Marz M, Ferg M, Rastegar S, Strahle U. 2015. Comprehensive expression map of transcription regulators in the adult zebrafish telencephalon reveals distinct neurogenic niches. J Comp Neurol 523:1202-1221.
Edelmann K, Glashauser L, Sprungala S, Hesl B, Fritschle M, Ninkovic J, Godinho L, Chapouton P. 2013. Increased radial glia quiescence, decreased reactivation upon injury and unaltered neuroblast behavior underlie decreased neurogenesis in the aging zebrafish telencephalon. J Comp Neurol 521:3099-3115.

Etchegaray JP, Chavez L, Huang Y, Ross KN, Choi J, MartinezPastor B, Walsh RM, Sommer CA, Lienhard M, Gladden A, Kugel S, Silberman DM, Ramaswamy S, Mostoslavsky G, Hochedlinger K, Goren A, Rao A, Mostoslavsky R. 2015. The histone deacetylase SIRT6 controls embryonic stem cell fate via TET-mediated production of 5-hydroxymethylcytosine. Nat Cell Biol 17:545-557.

Ficz G, Branco MR, Seisenberger S, Santos F, Krueger F, Hore TA, Marques CJ, Andrews S, Reik W. 2011. Dynamic regulation of 5-hydroxymethylcytosine in mouse ES cells and during differentiation. Nature 473:398-402.

Globisch D, Munzel M, Muller M, Michalakis S, Wagner M, Koch S, Bruckl T, Biel M, Carell T. 2010. Tissue distribution of 5-hydroxymethylcytosine and search for active demethylation intermediates. PLoS One 5:e15367.

Grandel H, Brand M. 2013. Comparative aspects of adult neural stem cell activity in vertebrates. Dev Genes Evol 223: 131-147.

Hahn MA, Qiu R, Wu X, Li AX, Zhang H, Wang J, Jui J, Jin SG, Jiang Y, Pfeifer GP, Lu Q. 2013. Dynamics of 5hydroxymethylcytosine and chromatin marks in mammalian neurogenesis. Cell Rep 3:291-300.

Irier HA, Jin P. 2012. Dynamics of DNA methylation in aging and Alzheimer's disease. DNA Cell Biol 31(Suppl 1):S42-48.

Ito S, D'Alessio AC, Taranova OV, Hong K, Sowers LC, Zhang Y. 2010. Role of Tet proteins in $5 \mathrm{mC}$ to $5 \mathrm{hmC}$ conversion, ES-cell self-renewal and inner cell mass specification. Nature 466:1129-1133.

Jin SG, Wu X, Li AX, Pfeifer GP. 2011. Genomic mapping of 5hydroxymethylcytosine in the human brain. Nucl Acids Res 39:5015-5024.

Kah O, Pellegrini E, Mouriec K, Diotel N, Anglade I, Vaillant C, Thieulant ML, Tong SK, Brion F, Chung BC, Pakdel F. 2009. [Oestrogens and neurogenesis: new functions for an old hormone. Lessons from the zebrafish.]. J Soc Biol 203:29-38.

Kizil C, Kaslin J, Kroehne V, Brand M. 2012. Adult neurogenesis and brain regeneration in zebrafish. Dev Neurobiol 72:429-461.

Kraus TF, Guibourt V, Kretzschmar HA. 2015. 5-Hydroxymethylcytosine, the "Sixth Base," during brain development and ageing. J Neural Trans 122:1035-1043.

Kriaucionis S, Heintz N. 2009. The nuclear DNA base 5hydroxymethylcytosine is present in Purkinje neurons and the brain. Science 324:929-930.

Li E, Bestor TH, Jaenisch R. 1992. Targeted mutation of the DNA methyltransferase gene results in embryonic lethality. Cell 69:915-926.

Lindsey BW, Tropepe V. 2006. A comparative framework for understanding the biological principles of adult neurogenesis. Prog Neurobiol 80:281-307.

Lindsey BW, Darabie A, Tropepe V. 2012. The cellular composition of neurogenic periventricular zones in the adult zebrafish forebrain. J Comp Neurol 520:2275-2316.

Ma DK, Marchetto MC, Guo JU, Ming GL, Gage FH, Song H. 2010. Epigenetic choreographers of neurogenesis in the adult mammalian brain. Nat Neurosci 13:1338-1344.

Maiti A, Drohat AC. 2011. Thymine DNA glycosylase can rapidly excise 5-formylcytosine and 5-carboxylcytosine: potential implications for active demethylation of $\mathrm{CpG}$ sites. J Biol Chem 286:35334-35338. 
März M, Chapouton P, Diotel N, Vaillant C, Hesl B, Takamiya M, Lam CS, Kah O, Bally-Cuif L, Strähle U. 2010. Heterogeneity in progenitor cell subtypes in the ventricular zone of the zebrafish adult telencephalon. Glia 58:870888.

März M, Schmidt R, Rastegar S, Strähle U. 2011. Regenerative response following stab injury in the adult zebrafish telencephalon. Dev Dyn 240:2221-2231.

Mellen M, Ayata P, Dewell S, Kriaucionis S, Heintz N. 2012. $\mathrm{MeCP} 2$ binds to $5 \mathrm{hmC}$ enriched within active genes and accessible chromatin in the nervous system. Cell 151: 1417-1430.

Meng H, Cao Y, Qin J, Song X, Zhang Q, Shi Y, Cao L. 2015. DNA Methylation, its mediators and genome integrity. Int J Biol Sci 11:604-617.

Menuet A, Pellegrini E, Brion F, Gueguen MM, Anglade I, Pakdel F, Kah O. 2005. Expression and estrogendependent regulation of the zebrafish brain aromatase gene. J Comp Neurol 485:304-320.

Munzel M, Globisch D, Bruckl T, Wagner M, Welzmiller V, Michalakis S, Muller M, Biel M, Carell T. 2010. Quantification of the sixth DNA base hydroxymethylcytosine in the brain. Angew Chem 49:5375-5377.

Okano M, Bell DW, Haber DA, Li E. 1999. DNA methyltransferases Dnmt3a and Dnmt3b are essential for de novo methylation and mammalian development. Cell 99:247257.

Pastor WA, Pape UJ, Huang Y, Henderson HR, Lister R, Ko M, McLoughlin EM, Brudno Y, Mahapatra S, Kapranov P, Tahiliani M, Daley GQ, Liu XS, Ecker JR, Milos PM, Agarwal S, Rao A. 2011. Genome-wide mapping of 5hydroxymethylcytosine in embryonic stem cells. Nature 473:394-397.

Pellegrini E, Mouriec K, Anglade I, Menuet A, Le Page Y, Gueguen MM, Marmignon MH, Brion F, Pakdel F, Kah O. 2007. Identification of aromatase-positive radial glial cells as progenitor cells in the ventricular layer of the forebrain in zebrafish. J Comp Neurol 501:150-167.

Pellegrini E, Coumailleau P, Kah O, Diotel N. 2015. Aromatase and estrogens: involvement in constitutive and regenerative neurogenesis in adult zebrafish. In: Duncan KA, editor. Estrogen effects on traumatic brain injury mechanisms of neuroprotection and repair. 51-71.

Raucci F, Di Fiore MM, Pinelli C, D’Aniello B, Luongo L, Polese G, Rastogi RK. 2006. Proliferative activity in the frog brain: a PCNA-immunohistochemistry analysis. J Chem Neuroanat 32:127-142.

Reik W. 2007. Stability and flexibility of epigenetic gene regulation in mammalian development. Nature 447:425-432.

Rodriguez Viales R, Diotel N, Ferg M, Armant O, Eich J, Alunni A, März M, Bally-Cuif L, Rastegar S, Strähle U. 2015. The helix-loop-helix protein id1 controls stem cell proliferation during regenerative neurogenesis in the adult zebrafish telencephalon. Stem Cells 33:892-903.

Rothenaigner I, Krecsmarik M, Hayes JA, Bahn B, Lepier A, Fortin G, Gotz M, Jagasia R, Bally-Cuif L. 2011. Clonal analysis by distinct viral vectors identifies bona fide neural stem cells in the adult zebrafish telencephalon and characterizes their division properties and fate. Development 138:1459-1469.

Schmidt R, Strähle U, Scholpp S. 2013. Neurogenesis in zebrafish - from embryo to adult. Neural Dev 8:3.

Suzuki MM, Bird A. 2008. DNA methylation landscapes: provocative insights from epigenomics. Nat Rev Genet 9: 465-476.

Szwagierczak A, Bultmann S, Schmidt CS, Spada F, Leonhardt H. 2010. Sensitive enzymatic quantification of 5hydroxymethylcytosine in genomic DNA. Nucl Acids Res 38:e181.

Tahiliani M, Koh KP, Shen Y, Pastor WA, Bandukwala H, Brudno Y, Agarwal S, lyer LM, Liu DR, Aravind L, Rao A. 2009. Conversion of 5-methylcytosine to 5-hydroxymethylcytosine in mammalian DNA by MLL partner TET1. Science 324: 930-935.

Tong SK, Mouriec K, Kuo MW, Pellegrini E, Gueguen MM, Brion F, Kah O, Chung BC. 2009. A cyp 19a1b-gfp (aromatase B) transgenic zebrafish line that expresses GFP in radial glial cells. Genesis 47:67-73.

Wu SC, Zhang Y. 2010. Active DNA demethylation: many roads lead to Rome. Nat Rev Mol Cell Biol 11:607-620.

Wullimann MF, Rupp B, Reichert H. 1996. Neuroanatomy of the zebrafish brain. A topological atlas. Basel, Switzerland: Birhaüser. p 1-144.

Xu Y, Xu C, Kato A, Tempel W, Abreu JG, Bian C, Hu Y, Hu D, Zhao B, Cerovina T, Diao J, Wu F, He HH, Cui Q, Clark E, Ma C, Barbara A, Veenstra GJ, Xu G, Kaiser UB, Liu XS, Sugrue SP, He X, Min J, Kato Y, Shi YG. 2012. Tet3 CXXC domain and dioxygenase activity cooperatively regulate key genes for Xenopus eye and neural development. Cell 151:1200-1213.

Yao B, Jin P. 2014. Unlocking epigenetic codes in neurogenesis. Genes Dev 28:1253-1271.

Zheng T, Lv Q, Lei X, Yin X, Zhang B. 2015. Spatial distribution of 5-hydroxymethyl Cytosine in rat brain and temporal distribution in striatum. Neurochem Res 40:688-697.

Zupanc GK. 2008. Adult neurogenesis and neuronal regeneration in the brain of teleost fish. J Physiol Paris 102:357373.

Zupanc GK, Hinsch K, Gage FH. 2005. Proliferation, migration, neuronal differentiation, and long-term survival of new cells in the adult zebrafish brain. J Comp Neurol 488: 290-319. 